\title{
The Endogenous Calcium Buffer and the Time Course of Transducer Adaptation in Auditory Hair Cells
}

\author{
A. J. Ricci, Y-C. Wu, and R. Fettiplace \\ Department of Physiology, University of Wisconsin Medical School, Madison, Wisconsin 53706
}

Mechanoelectrical transducer currents in turtle auditory hair cells adapt to maintained stimuli via a $\mathrm{Ca}^{2+}$-dependent mechanism that is sensitive to the level of internal calcium buffer. We have used the properties of transducer adaptation to compare the effects of exogenous calcium buffers in the patch electrode solution with those of the endogenous buffer assayed with perforated-patch recording. The endogenous buffer of the hair bundle was equivalent to 0.1-0.4 mm BAPTA and, in a majority of cells, supported adaptation in an external $\mathrm{Ca}^{2+}$ concentration of $70 \mu \mathrm{M}$ similar to that in turtle endolymph. The endogenous buffer had a higher effective concentration, and the adaptation time constant was faster in cells at the high-frequency end than at the low-frequency end of the cochlea. Experiments using buffers with different $\mathrm{Ca}^{2+}$-binding rates or dissociation constants indicated that the speed of adaptation and the rest- ing open probability of the transducer channels could be differentially regulated and imply that the endogenous buffer must be a fast, high-affinity buffer. In some hair cells, the transducer current did not decay exponentially during a sustained stimulus but displayed damped oscillations at a frequency $(58-230 \mathrm{~Hz})$ that depended on external $\mathrm{Ca}^{2+}$ concentration. The gradient in adaptation time constant and the tuned transducer current at physiological levels of calcium buffer and external $\mathrm{Ca}^{2+}$ suggest that transducer adaptation may contribute to hair cell frequency selectivity. The results are discussed in terms of feedback regulation of transducer channels mediated by $\mathrm{Ca}^{2+}$ binding at two intracellular sites.

Key words: adaptation; BAPTA; calcium buffers; feedback; hair cell; mechanoelectrical transduction; frequency tuning
$\mathrm{Ca}^{2+}$ regulates a variety of intracellular processes, but its efficiency as a signaling agent depends on the degree of sequestration by cytoplasmic calcium buffers. Mobile buffers like calbindin and parvalbumin are especially important because they have a high $\mathrm{Ca}^{2+}$ affinity and can be continually replenished by diffusion of free buffer into a region of elevated $\mathrm{Ca}^{2+}$ (Roberts, 1994). Consequently, such buffers can establish standing gradients in free $\mathrm{Ca}^{2+}$ in the vicinity of a $\mathrm{Ca}^{2+}$ source like a membrane ion channel (Neher, 1986; Stern, 1992); they can also affect the magnitude and spatial extent of a $\mathrm{Ca}^{2+}$ transient caused by a brief channel opening (Chard et al., 1993). In patch-electrode recordings, an extrinsic calcium buffer is normally added to the internal solution. When the roles of calcium-dependent processes are being studied, the performance of this extrinsic buffer should, as far as possible, match the endogenous calcium buffer. The characteristics of the native buffer can be estimated by comparing the behavior of the cell in whole-cell recording to that in perforated-patch recording in which proteinaceous calcium buffers are retained in the cytoplasm (Zhou and Neher, 1993; Tucker and Fettiplace, 1996).

$\mathrm{Ca}^{2+}$ plays an important signaling role in hair cells by regulating adaptation of the mechanoelectrical transducer channels (Eatock et al., 1987; Assad et al., 1989; Crawford et al., 1989). In

Received May 29, 1998; revised July 22, 1998; accepted July 24, 1998.

This work was supported by a National Institutes of Health Grant 5RO1 DC 01362 to R.F. from the National Institutes on Deafness and other Communicative Disorders. We thank Mark Gray-Keller for helpful comments.

Correspondence should be addressed to Robert Fettiplace, 185, Medical Sciences Building, 1300 University Avenue, Madison, WI 53706. Dr. Wu's present address: SAP Labs, 3475 Deer Creek Road, Palo Alto, CA 94304.

Copyright (C) 1998 Society for Neuroscience $0270-6474 / 98 / 188261-17 \$ 05.00 / 0$ response to a sustained deflection of the hair bundle, the transducer current rapidly activates but subsequently declines from its peak amplitude. This process of adaptation adjusts the operating range of the transducer to preserve a high sensitivity (Eatock et al., 1987) via a mechanism that requires entry of $\mathrm{Ca}^{2+}$ through the open transducer channels (Assad et al., 1989; Crawford et al., 1989; Ricci and Fettiplace, 1998). In turtle hair cells, the time course of adaptation and the fraction of transducer current activated at the position of the unperturbed bundle depend both on external $\mathrm{Ca}^{2+}$ concentration and on the level of intracellular calcium buffer (Ricci and Fettiplace, 1997, 1998). To assess the physiological contribution of transducer adaptation, it is important to have an estimate of the level of endogenous $\mathrm{Ca}^{2+}$ buffer in the hair bundle. In the turtle cochlea, the hair cells are arranged tonotopically, the characteristic frequency of a cell varying with position along the cochlea (Crawford and Fettiplace, 1980). The time course of adaptation recorded with electrodes containing a fixed concentration of exogenous buffer also depends on hair cell location (Ricci and Fettiplace, 1997). Do the tonotopic variations in adaptation persist under physiological conditions?

To address these topics, we have used the properties of transducer adaptation to compare the effects of exogenous calcium buffers like BAPTA and EGTA introduced through the patch electrode with those of the endogenous buffer assayed with perforated-patch recording. By recording transducer currents at two separate locations, we provide evidence for a gradient in both the calcium buffer and the adaptation time constant. An unexpected finding was that under ionic conditions resembling those in vivo, the voltage-clamped transducer current displayed resonance-like behavior signifying that mechanotransduction may contribute to the frequency selectivity of the cell. 


\section{MATERIALS AND METHODS}

Preparation, recording, and stimulation. The preparation and method of hair cell stimulation in the intact basilar papilla were similar to procedures previously detailed (Crawford and Fettiplace, 1985; Ricci and Fettiplace, 1997). Turtles (Trachemys scripta elegans, carapace length $100-125 \mathrm{~mm}$ ) were decapitated, and the cochlear duct and lagena were dissected out. The cochlea was opened, and the tectorial membrane was lifted off after $\sim 20$ min digestion in saline (composition, in $\mathrm{mm}: \mathrm{NaCl}$, $125 ; \mathrm{KCl}, 4 ; \mathrm{CaCl}_{2}, 2.8 ; \mathrm{MgCl}_{2}, 2.2 ; \mathrm{Na}$ pyruvate, 2; glucose 8 ; and Na-HEPES, $10, \mathrm{pH} 7.6$ ) containing up to $0.1 \mathrm{mg} / \mathrm{ml}$ of protease (Sigma type XXIV). The preparation was transferred to a Sylgard well in the recording chamber and secured, hair bundles uppermost, with strands of dental floss tensioned on insect pins; the tension could be adjusted so that most of the hair bundles lay in the same focal plane. The chamber was mounted on the stage of a Zeiss Axioskop FS microscope and viewed with Nomarski optics through a $63 \times$ water-immersion objective $(\mathrm{NA}=$ 0.9), a $1.6 \times$ optovar, and a Hamamatsu C2400 CCD camera.

Whole-cell currents were measured with a List EPC-7 amplifier attached to a borosilicate patch electrode. The patch electrode was advanced from the abneural edge of the basilar papilla along a track at the level of the cell bodies rupturing intervening supporting cells to make contact with the basolateral aspect of a hair cell (Ricci and Fettiplace, 1997). At the end of an experiment, the location of the hair cell and the total length of the basilar papilla were documented. Most recordings were made from cells in two regions, one at $\sim 0.3$ and the other at $\sim 0.6$ of the distance along the cochlea from the low-frequency (lagenar) end. The properties of the transducer current depended on the maximum amplitude of the current (Ricci and Fettiplace, 1997), variations that introduced substantial scatter in the measured parameters. To minimize such variation, cells with current amplitudes less than half of the maximum observable at a given position were normally excluded from the averages. Unless otherwise stated, values of current parameters are given as means \pm 1 SEM. Transducer currents and other experimental signals were stored on a Sony PCM instrumentation recorder at a band width of $0-20 \mathrm{kHz}$. Experiments were performed at $22-24^{\circ} \mathrm{C}$.

Hair bundles were stimulated with a rigid glass pipette (tip firepolished to $\sim 1 \mu \mathrm{m}$ in diameter) cemented to a piezoelectric bimorph (Crawford et al., 1989). The bimorph was driven differentially with voltage steps, filtered with an 8 -pole bessel at $3 \mathrm{kHz}$ and amplified through a high-voltage driver of 20 -fold gain, to yield a fast stimulator with a $10-90 \%$ rise time of $\sim 100 \mu \mathrm{sec}$. The time course of the glass probe was calibrated by projecting its image onto a pair of photodiodes as described previously (Crawford and Fettiplace, 1985). The displacement noise in the motion of the probe was $<5 \mathrm{~nm}$ peak-to-peak. The glass probe was acid-cleaned at the start of each experiment so that it would adhere to the hair bundle membrane, thus ensuring that the bundle would follow faithfully both positive and negative movements of the probe.

Extracellular and intracellular solutions. The preparation was perfused with a saline of composition (in $\mathrm{mM}$ ): $\mathrm{NaCl}, 128 ; \mathrm{KCl}, 0.5 ; \mathrm{CaCl}_{2}, 2.8$; $\mathrm{MgCl}_{2}, 2.2$; Na pyruvate, 2; glucose 8; and Na-HEPES, 10, pH 7.6. The upper surface of the hair cell epithelium facing the endolymphatic compartment was separately and continuously perfused by a large pipette, $100 \mu \mathrm{m}$ internal diameter, introduced into the cochlear duct. The perfusion pipette was connected to a six-inlet manifold (Warner Instruments, Hamden, CT) fed from a peristaltic pump (Gilson, Madison WI), a given inlet being selected by means of a remotely controlled miniature solenoid valve (Lee Products, Westbrook, CT). The perfusion rate was kept low to prevent inadvertent stimulation of the bundles and to localize the fluid stream around the cell being studied. The exchange time for wash-in of the endolymph solution was $\sim 1 \mathrm{~min}$ but, in practice, $3-5 \mathrm{~min}$ were allowed after a solution change before making a new measurement. The artificial endolymph solutions had ionic compositions (in $\mathrm{mM}$ ) of: $\mathrm{NaCl}, 130$; KCl, 0.5; Na pyruvate, 2; glucose 8; and HEPES, 10, pH 7.6, with free $\mathrm{Ca}^{2+}$ concentrations of $0.07,0.35,1$, and $2.8 \mathrm{mM}$. The $\left[\mathrm{Ca}^{2+}\right]$ in all solutions was measured with a calcium electrode (MI 100, Microelectrodes Inc., Londonderry, $\mathrm{NH}$ ). It should be noted that endolymph in vivo also contains a high $\mathrm{K}^{+}$concentration, but this was not used as the major monovalent ion in these experiments because it tended to shorten the recording time, possibly because of $\mathrm{K}^{+}$leakage to the basolateral surface of the hair cell.

Whole-cell electrodes were filled with an internal solution of composition (in mM): CsCl, 125; $\mathrm{Na}_{2} \mathrm{ATP}, 3 ; \mathrm{MgCl}_{2}, 2$; and Cs-HEPES, 10 , adjusted to $\mathrm{pH} 7.2$ with $\mathrm{CsOH}$, with the addition of various amounts of the calcium buffers: BAPTA, 5,5'-dibromo-BAPTA, 5-nitro-BAPTA,
5,5',6,6'-tetrafluoro-BAPTA (Molecular Probes, Eugene, OR), or EGTA (Fluka, Ronkonkoma, NY). Buffer concentrations of $0.1-10 \mathrm{~mm}$ were used, and with the highest concentration, the $\mathrm{CsCl}$ was reduced to keep the osmolarity constant. After application of up to $50 \%$ series resistance compensation, the electrode access resistance was 3-10 $\mathrm{M} \Omega$, which gave a recording time constant of $45-150 \mu \mathrm{sec}$. Transducer currents were measured at a holding potential which, when corrected for the junction potential introduced by the internal solution, was $-90 \mathrm{mV}$.

Perforated-patch recordings. The technique for perforated-patch recordings was similar to that originally described (Horn and Marty, 1988; Rae et al., 1991) and recently applied to isolated hair cells (Tucker and Fettiplace, 1996). The electrode solution contained (in mM): CsAspartate, $110 ; \mathrm{CsCl}, 15 ; \mathrm{Na}_{2} \mathrm{ATP}, 3 ; \mathrm{MgCl}_{2}, 2 ; \mathrm{Cs}_{4}$-BAPTA, 0.1 or 1 ; and Na-HEPES, 10, neutralized to $\mathrm{pH} 7.2$ with $\mathrm{CsOH}$. For each experiment, $2.4 \mathrm{mg}$ of nystatin (Calbiochem, San Diego, CA) was dissolved in $10 \mu \mathrm{l}$ of dry dimethyl sulfoxide and diluted 1:1000 into the stock intracellular solution. The patch pipette was tip-filled with antibiotic-free stock solution and back-filled with the nystatin solution to prevent the antibiotic leaking into the bath during penetration of the papilla and sealing to the membrane. Access resistances in perforated-patch mode were 11-29 M $\Omega$ (mean $\pm \mathrm{SD}=17 \pm 5 \mathrm{M} \Omega$ ) which, after applying up to $40 \%$ series resistance compensation, were reduced to $7-23 \mathrm{M} \Omega$ (mean $=12 \pm 4$ $\mathrm{M} \Omega$ ). Potentials were adjusted for the junction potential between the Cs aspartate solution and the external saline $(\sim 10 \mathrm{mV}$ greater than that measured with the $\mathrm{CsCl}$ internal solution) to produce a holding potential of $-90 \mathrm{mV}$.

Diff usion of the nystatin to the tip of the electrode and perforation of the enclosed patch could take $10-15$ min after attaining a seal, and during this period there was some concern that the patch had ruptured spontaneously. To eliminate this possibility, in early experiments, a fluorescent marker, Lucifer yellow was added at $1 \mathrm{~mm}$ to the electrode solution. The preparation was then viewed with epifluorescence illumination from a $100 \mathrm{~W}$ mercury lamp, passed through a remotely controlled Uniblitz shutter and a 450-490 excitation filter. The fluorescence emission was long-pass filtered at $520 \mathrm{~nm}$ and imaged with an intensified CCD camera (Hamamatsu C2400). During the perforated-patch recording, the fluorescent dye was confined to the electrode, but after deliberately rupturing the patch, the dye quickly gained access to the cell interior (Fig. 1).

Fluorescence from the Lucifer yellow (molecular weight, $457 \mathrm{Da}$ ) would typically invade the cell body and hair bundle to reach a steady state within 2 min of patch rupture, which suggests that the contents of the patch solution quickly diffuse into the cell. From the electrode resistances, it can be estimated (Oliva et al., 1988) that the time constant of "wash-in" for a substance the size of BAPTA is $\sim 2-3 \mathrm{~min}$. In practice, with whole-cell recording, at least 5 min were allowed after breaking the membrane patch for the electrode solution and especially the exogenous calcium buffers, to exchange with the cytoplasmic constituents. After such a period of equilibration there were no marked changes in the characteristics of the transducer current for the duration of a whole-cell recording that might last $30 \mathrm{~min}$. It seems likely, therefore, that the concentration of exogenous buffer in the cell was comparable to that in the electrode. If the exogenous buffer did not fully equilibrate in the hair bundle and had a lower concentration than in the pipette, this would cause the concentration of endogenous buffer to be overestimated.

During a perforated-patch recording, there is no exchange of the larger molecules between the cell and the electrode, although there is an exchange of ions via the nystatin pores. Nevertheless, there were significant drifts in the properties of the transducer current during the first few minutes of a recording. In particular, the current grew in amplitude, and the adaptation became faster. No measurements were taken until the transducer responses had stabilized, the time course of which was accelerated by exposing the hair bundle to low- $\mathrm{Ca}^{2+}$ endolymph. One explanation for these changes is that, before recording, the hair cells were depolarized and $\mathrm{Ca}^{2+}$-loaded but were able to extrude the load after exposure to low $\mathrm{Ca}^{2+}$ and voltage clamping at $-90 \mathrm{mV}$, at which the voltage-gated $\mathrm{Ca}^{2+}$ channels are not activated.

\section{RESULTS}

\section{The endogenous buffer concentration in the hair bundle}

Hair cell transducer currents were characterized by assaying two separate parameters, the time constant of adaptation and the fraction of total transducer current turned on at rest. The adap- 

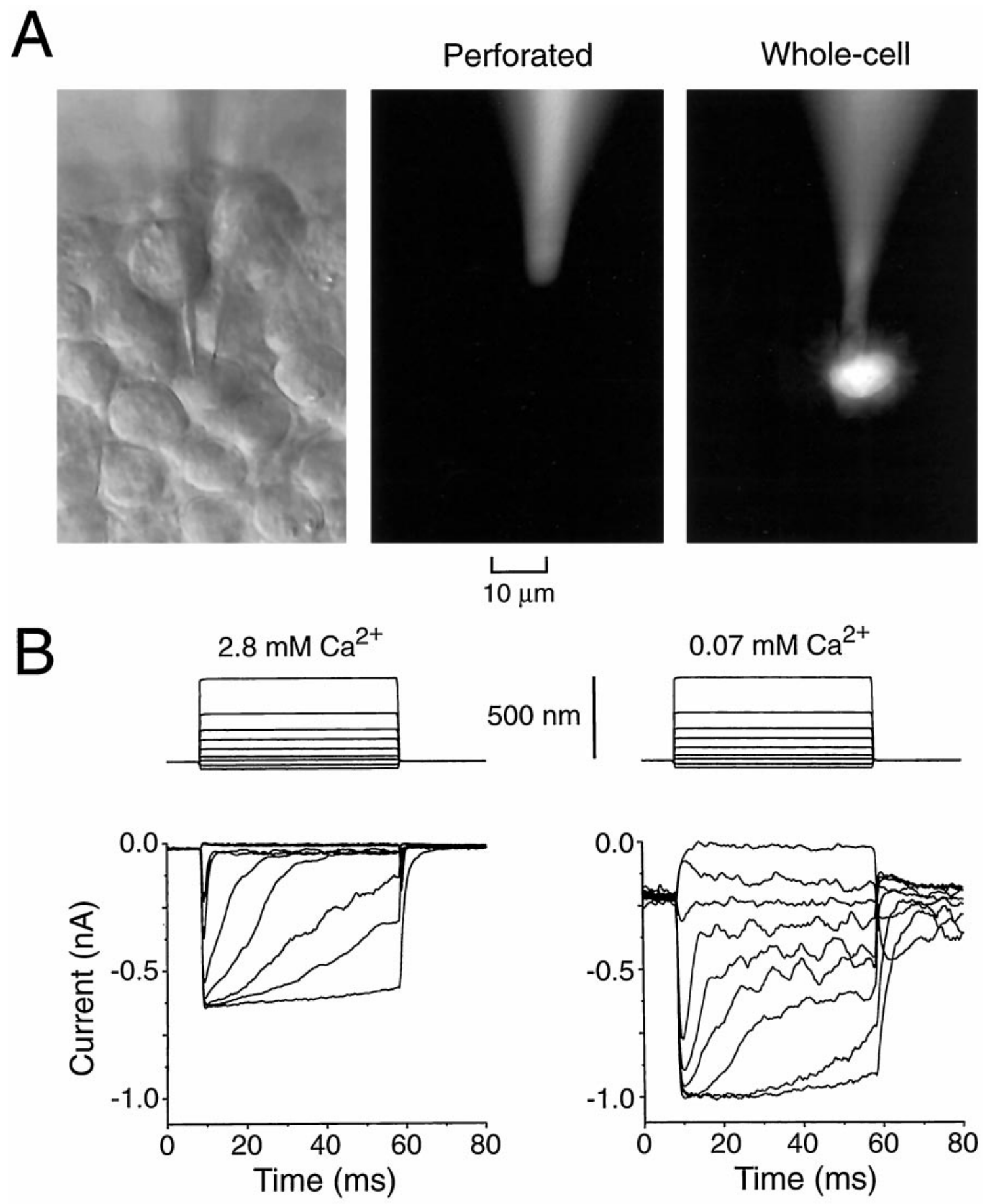

Figure 1. Perforated-patch recordings of the hair cell transducer current. $A$, Photomicrographs of part of the high-frequency region of the turtle basilar papilla viewed with Nomarski optics (left) and in epifluorescence illumination (middle and right). The focal plane is about halfway down the hair cell from the hair bundle. The patch electrode contained Lucifer yellow, which cannot enter the cell in the perforated-patch mode (middle) but gains access to the cytoplasm on attaining the whole-cell configuration (right). B. Families of hair cell transducer currents obtained with perforated-patch recording in external solutions superfusing the hair bundle that contained $2.8 \mathrm{~mm}$ and $0.07 \mathrm{mM} \mathrm{Ca}^{2+}$. Note that the transducer currents still displayed adaptation in a $\mathrm{Ca}^{2+}$ concentration of $0.07 \mathrm{~mm}$ resembling that in turtle endolymph. The maximum current was larger in low $\mathrm{Ca}^{2+}$ because of relief of external block of the transducer channels (Ricci and Fettiplace, 1998). The time course of the bundle deflection is shown above the current records that are averages of 5-25 responses. In this and all subsequent figures, the holding potential was $-90 \mathrm{mV}$, and the zero on the ordinate scale corresponds to the current level obtained with a large negative stimulus, at which the transducer conductance was fully turned off.

tation time constant was obtained by fitting the decline in the current during a sustained deflection of the hair bundle that evoked less than a half-maximal response (Fig. 2). Whole-cell measurements were made with intracellular solutions containing
$0.1,1$, or $10 \mathrm{~mm}$ concentrations of the calcium buffer, BAPTA, in a range of external $\mathrm{Ca}^{2+}$ concentrations (0.07-2.8 mM). As reported previously (Ricci and Fettiplace, 1997), both parameters of transduction depended on the level of intracellular BAPTA 


\section{$2.8 \mathrm{mM} \mathrm{Ca}^{2+}$}
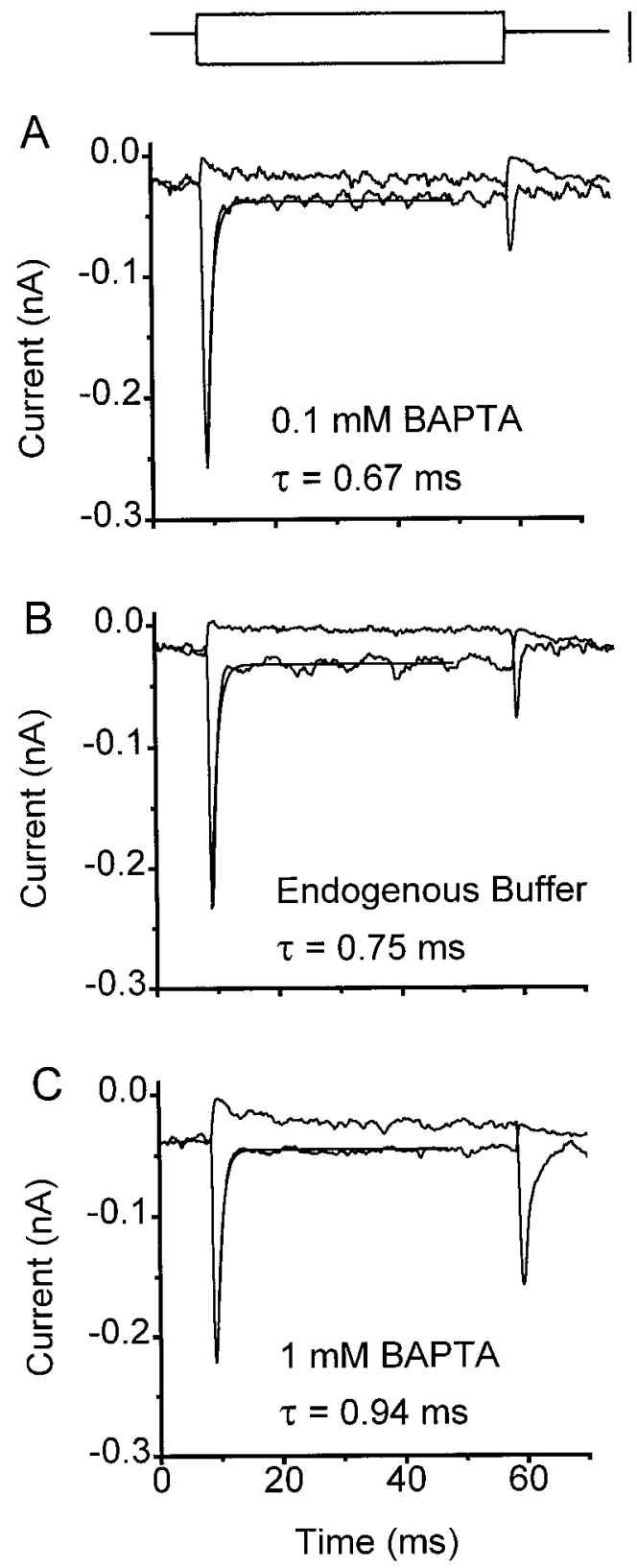

\section{$0.07 \mathrm{mM} \mathrm{Ca}^{2+}$}

$150 \mathrm{~nm}$
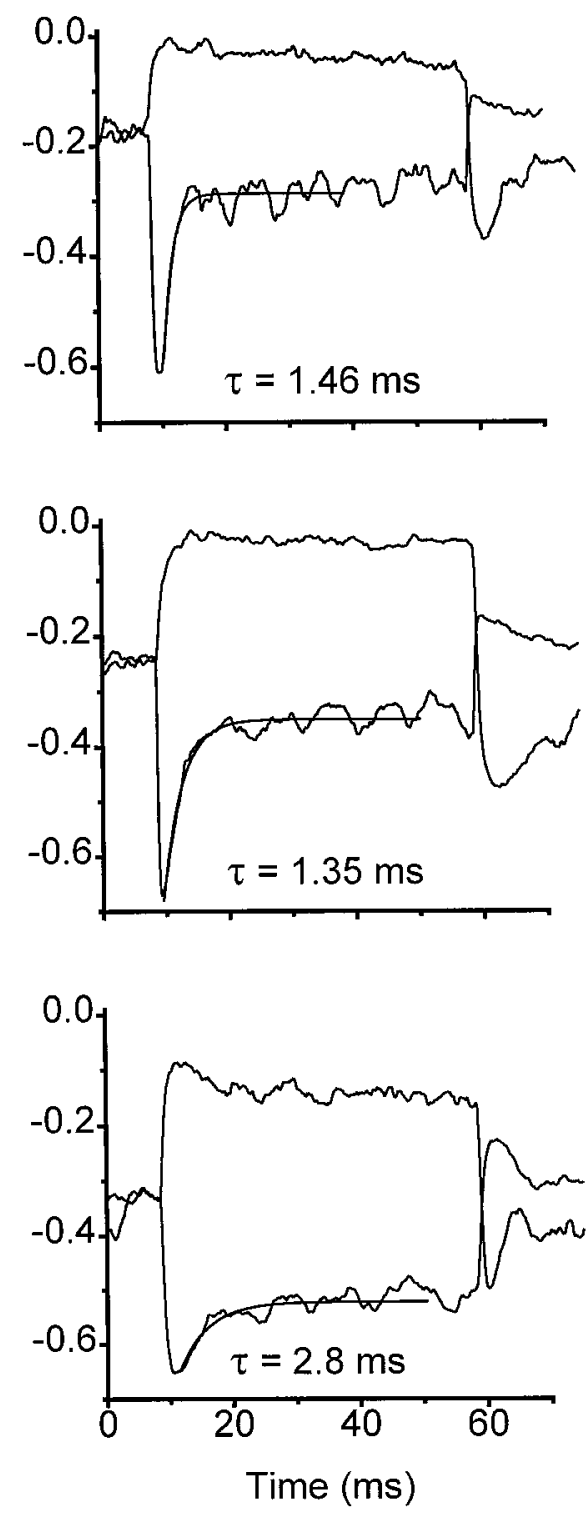

Figure 2. Transducer currents recorded in three high-frequency hair cells under different intracellular calcium-buffering conditions. $A$, Whole-cell electrodes containing $0.1 \mathrm{~mm}$ BAPTA with perforated-patch recording for the endogenous buffer $(B)$ and with whole-cell electrodes containing $1 \mathrm{mM}$ BAPTA $(C)$. Currents (averages of 25 responses) to small positive and negative bundle deflections are shown in external solutions containing 2.8 mM and $0.07 \mathrm{mM} \mathrm{Ca}^{2+}$. The zero on the ordinate scale corresponds to the current level obtained with a large negative stimulus in which the transducer conductance was fully turned off. Recordings were characterized by measuring the time constant of adaptation, $\tau$, and the fraction of total current activated at rest before the stimulus. $\tau$ was obtained from single exponential fits that are shown superimposed on the positive responses. Note that the time constants of adaptation for the perforated-patch recording fall between those for 0.1 and $1.0 \mathrm{~mm}$ BAPTA. The timing and size of the stimulus, depicted above the currents, is the same in all three cells. Maximum current amplitudes in 2.8 and $0.07 \mathrm{~mm} \mathrm{Ca}^{2+}$, respectively were 1.2 and $2.0 \mathrm{nA}(A)$, 0.65 and $1.1 \mathrm{nA}(B)$, and 0.66 and $1.2 \mathrm{nA}(C)$.

(see Figs. 2, 3, 5). An increase in BAPTA slowed the time course of adaptation and increased the fraction of current activated at rest. The properties of adaptation also vary with hair cell location (Ricci and Fettiplace, 1997) and it was important, therefore, to characterize cells in defined cochlear locations. Data were collected from hair cells at approximately one-third of the distance $(d=0.29 \pm 0.05)$ and two-thirds of the distance $(d=0.60 \pm 0.06)$ along the basilar papilla, where $d$ is the distance of the cell from the low-frequency end normalized to the total length of the papilla. Based on the tonotopic organization of the turtle basilar papilla (Crawford and Fettiplace, 1980; Wu and Fettiplace, 1996), these two regions possess hair cells tuned to frequencies of $\sim 90$ and $200 \mathrm{~Hz}$, respectively. As discussed later, the quantitative effects of the buffer differed in the two locations. 


\section{Low Frequency $(\mathrm{d}=0.29)$}
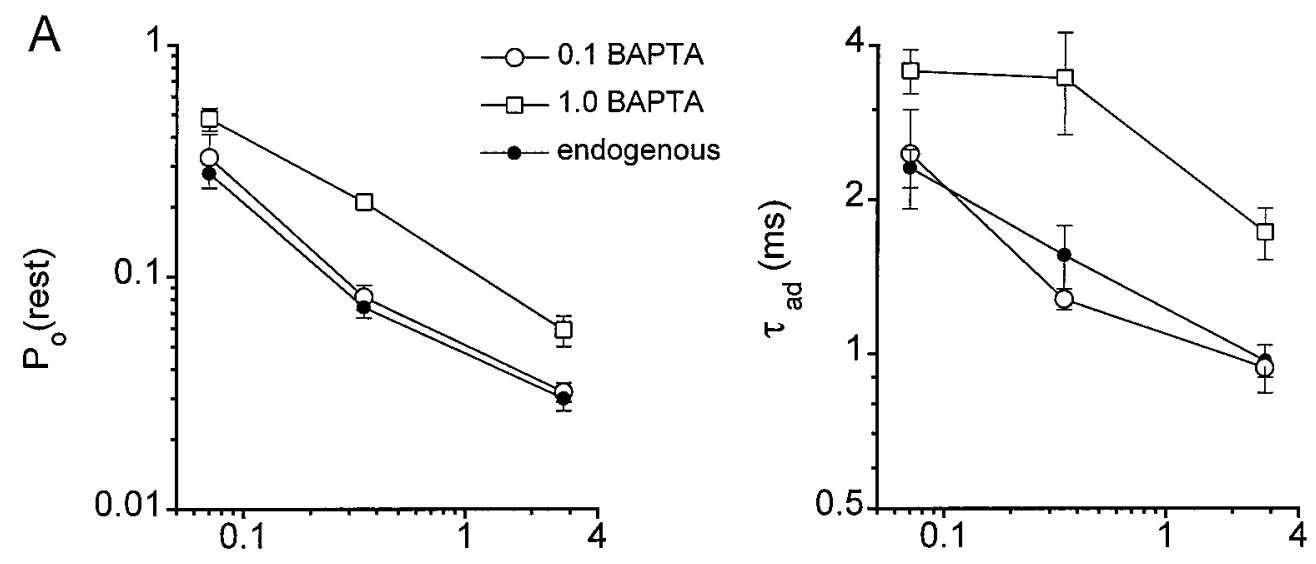

Figure 3. Estimates of the concentration of endogenous calcium buffer in two cochlear locations. Plots of the fraction of total current activated at rest $\left[P_{\mathrm{O}}\right.$ (rest) $]$ and the time constant of adaptation $\left(\tau_{\mathrm{ad}}\right)$ as a function of the external $\mathrm{Ca}^{2+}$ concentration bathing the hair bundle for low-frequency hair cells $(A)$ and high-frequency hair cells
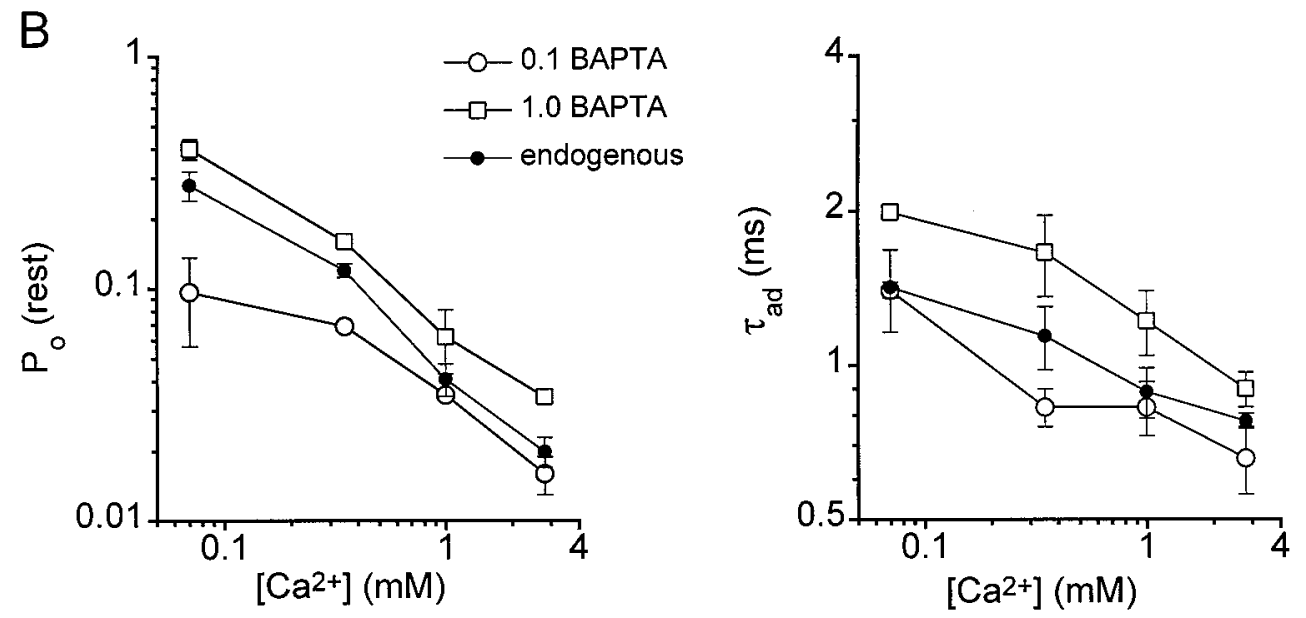

$(B)$. The cell location is denoted by $d$, the fractional distance along the basilar membrane from the low-frequency end. Each measurement is the mean \pm 1 SEM obtained from records similar to those in Figure 2 for whole-cell recordings with 0.1 or $1 \mathrm{~mm}$ BAPTA (open symbols) and with perforatedpatch recordings (filled symbols). Numbers of cells included in perforated-patch, 0.1 , and $1 \mathrm{~mm}$ BAPTA measurements, respectively, were 7,10 , and 14 (low frequency) and 7, 7, and 23 (high frequency). Note the perforated-patch results are comparable to $0.1 \mathrm{~mm}$ BAPTA at the lowfrequency location but fall between 0.1 and $1 \mathrm{~mm}$ BAPTA at the highfrequency location.

Transducer currents recorded with perforated-patch electrodes had similar properties to those measured with whole-cell electrodes. In particular, the currents were large with amplitudes up to $1 \mathrm{nA}$ and displayed fast adaptation during a maintained stimulus. The current size depended on the position of the hair cell and had a maximum value of $0.714 \pm 0.07 \mathrm{nA}(n=7)$ at the low-frequency location and $1.10 \pm 0.13 \mathrm{nA}(n=5)$ at the highfrequency location in $70 \mu \mathrm{M}$ external $\mathrm{Ca}^{2+}$. This concentration is comparable to that in turtle endolymph, the extracellular solution bathing the hair bundles in vivo (65 $\mu \mathrm{M}$; Crawford et al., 1991). Of special note is the fact that 9 of the 12 cells recorded at both cochlear locations retained adaptation in $70 \mu \mathrm{M}$ external $\mathrm{Ca}^{2+}$. In contrast, with intracellular BAPTA concentrations $>1 \mathrm{~mm}$, adaptation often disappeared when the external $\mathrm{Ca}^{2+}$ was reduced to $<0.1 \mathrm{~mm}$ (Ricci and Fettiplace 1997). These results suggest that the concentration of endogenous buffer is sufficiently low to support adaptation in an external solution resembling endolymph.

Plots of the two transducer parameters, the adaptation time constant and the fraction of current activated at the unperturbed position of the hair bundle, are shown in Figure 3 for the different buffer conditions. An important observation is that both parameters were similarly affected by BAPTA and by the endogenous buffer. For the low-frequency location, the endogenous buffer is equivalent to $0.1 \mathrm{~mm}$ BAPTA, using either the adaptation time constant or the fraction of current turned on at rest as the assay (Fig. 3A). At the high-frequency location, the measurements for the endogenous buffer lie between those for 0.1 and $1.0 \mathrm{~mm}$ BAPTA (Fig. 3B). Interpolation of the values at the different $\mathrm{Ca}^{2+}$ levels indicates that the endogenous buffer is equivalent to $0.46 \pm 0.10 \mathrm{~mm}$ BAPTA based on the fraction of current turned on at rest and $0.33 \pm 0.12 \mathrm{~mm}$ BAPTA based on the adaptation time constant. Combining these values yields an effective buffer concentration of $0.4 \mathrm{~mm}$ BAPTA at the high frequency location, which is significantly higher than in cells at the low-frequency location. These results suggest that there may be a gradient in endogenous buffer along the cochlea.

In three experiments it was possible first to characterize the currents with perforated-patch recording and then attain a wholecell condition, thus providing an internal control. As found in earlier experiments (Tucker and Fettiplace, 1996) the whole-cell recordings remained stable despite the leakage into the cell of the pore-forming nystatin. The perforated patch gave consistent measurements for $>30 \mathrm{~min}$, and then the patch was ruptured to attain a whole-cell recording. After waiting a further $5 \mathrm{~min}$ for the electrode and cytoplasmic solutions to equilibrate, allowing en- 


\begin{tabular}{|c|c|c|c|c|c|c|}
\hline Location & $F_{\mathrm{O}}(\mathrm{Hz})$ & $I_{\max }(\mathrm{nA})$ & $\tau_{\mathrm{ad}}(\mathrm{msec})$ & $P_{\mathrm{o}}($ rest $)$ & $N_{\text {ad }} / N_{\text {total }}$ & $\mathrm{Ca}^{2+}$ buffer \\
\hline 0.29 & 90 & $0.71 \pm 0.07$ & $2.5 \pm 0.5$ & $0.28 \pm 0.11$ & $4 / 7$ & $0.1 \mathrm{~mm}$ \\
\hline 0.60 & 200 & $1.10 \pm 0.13$ & $1.4 \pm 0.3$ & $0.28 \pm 0.13$ & $5 / 5$ & $0.4 \mathrm{~mm}$ \\
\hline
\end{tabular}

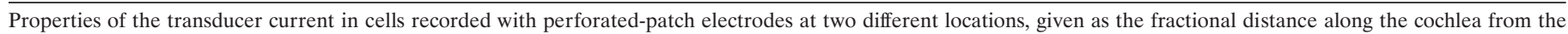

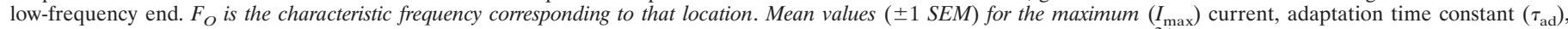

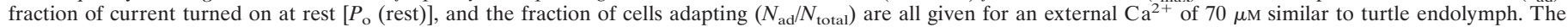
endogenous calcium buffer for cells at each location is expressed in terms of the equivalent BAPTA concentration.

dogenous buffer to wash out, a new family of transducer currents was taken. The transition from perforated-patch to whole-cell produced little alteration in the peak current, a small increase in the fraction of current activated at rest $(0.033 \pm 0.005$ compared with $0.025 \pm 0.003$ ), and a slowing of the adaptation time constant from $0.75 \pm$. $0.03 \mathrm{msec}$ to $1.01 \pm 0.13 \mathrm{msec}$. The changes are comparable to those obtained from the averaged measurements in different cells and are consistent with the notion that the buffering capacity of $1 \mathrm{~mm}$ BAPTA is greater than the native buffer.

\section{Relationship between adaptation time constant and transducer current magnitude}

The perforated-patch recordings, summarized in Table 1, provide some indication of the physiological performance of the transducer at the two positions in the cochlea. In an external $\mathrm{Ca}^{2+}$ concentration of $70 \mu \mathrm{M}$, the adaptation time constant was faster in cells tuned to higher frequencies $(1.4 \pm 0.3 \mathrm{msec}, n=5)$ than in those tuned to low frequencies $(2.5 \pm 0.5 \mathrm{msec}, n=4)$. Because a higher buffer concentration would slow adaptation, the different concentrations of endogenous buffer in cells at the two locations would, if anything, minimize the difference in time constant. What other factors might be responsible for the difference in adaptation kinetics? Cells at the high-frequency location had a larger mean current than those at the low-frequency location (Table 1). To eliminate the contribution of the current magnitude, we compared cells from the two locations that had similar sizes of transducer current. Despite the overall differences in mean current, there was substantial variation in maximal current at both positions, presumably caused by a variable degree of mechanical damage to the transduction apparatus during dissection. We could, thus, select populations of cells having closely matched amplitudes of currents obtained in $2.8 \mathrm{~mm}$ external $\mathrm{Ca}^{2+}$ and $1 \mathrm{~mm}$ internal BAPTA, for which the most extensive measurements were available. Six low-frequency cells (fractional distance along papilla, $d=0.17-0.28$ ) had a mean transducer current of $535 \pm 44 \mathrm{pA}$ and an adaptation time constant of $1.41 \pm$ 0.18 msec. By comparison, five high-frequency cells $(d=0.55-$ 0.75 ) had a virtually identical mean transducer current of $530 \pm$ $27 \mathrm{pA}$ but a significantly faster adaptation time constant of $0.94 \pm$ 0.13 msec. Because hair bundles in high-frequency cells would have more stereocilia (Hackney et al., 1993), the mean current per stereocilium would in fact be smaller and yet generate faster adaptation.

As another approach to this question, a population of cells was selected, also from measurements in $2.8 \mathrm{~mm}$ external $\mathrm{Ca}^{2+}$ and 1 $\mathrm{mM}$ internal BAPTA, to span the widest current range. This procedure required including some cells that, because of their small current size, would normally not be used to evaluate the average performance at a given position (see Materials and Methods). For these populations, the adaptation time constant is plotted in Figure 4 against the maximum transducer current per stereocilium. The latter values were calculated by normalizing the peak currents to the expected number of stereocilia at the respective positions (Hackney et al., 1993): 60 stereocilia per bundle at $d=0.22$ and 90 stereocilia per bundle at $d=0.64$. Although for both cochlear locations there is an inverse relationship between adaptation time constant and current per stereocilium, the measurements at the two locations do not overlap and, for a given current size, the time constant is faster in high-frequency cells.

We do not fully understand the etiology of the relationship between current magnitude and adaptation time constant in cells in which the current was reduced, presumably because of loss of channels by damage to the hair bundles (Ricci and Fettiplace, 1997). However, it is clear from the results in Figure 4 that some aspect of the transducer channels or their regulation must vary with hair cell location to account for the difference in adaptation time constant at the different cochlear locations. Two types of mechanism may be considered. The fraction of transducer current carried by $\mathrm{Ca}^{2+}$ may differ, implying a difference in transducer channel properties. Alternatively, a given rise in intracellular $\mathrm{Ca}^{2+}$ may be more efficacious because of differences in the $\mathrm{Ca}^{2+}$-binding site or in the kinetics of the adaptation process regulating channel opening. Both explanations imply that the tonotopic frequency map in the turtle cochlea involves not only a gradient in the properties of the voltage-dependent channels that underlie electrical tuning (Wu et al., 1995), but also a variation in the mechanoelectrical transduction apparatus.

\section{Other calcium buffers}

Another exogenous calcium buffer often used in patch recordings is EGTA, which has a similar $\mathrm{Ca}^{2+}$ dissociation constant to BAPTA but an $\sim 150$-fold slower rate of $\mathrm{Ca}^{2+}$ binding (Tsien, 1980; Naraghi and Neher, 1997). Recordings from high-frequency cells using patch solutions containing EGTA showed that it was less effective in influencing transducer adaptation than BAPTA. Thus, transducer currents in the presence of $10 \mathrm{~mm}$ intracellular EGTA retained fast adaptation, whereas with the same concentration of BAPTA, the adaptation was substantially slowed (Fig. $5 A)$. However, the fraction of current activated at rest was sensitive to the EGTA. Collected results (Fig. 5B) showed that $10 \mathrm{~mm}$ EGTA had a comparable efficacy to $1 \mathrm{~mm}$ BAPTA in affecting the fraction of current activated at rest but was equivalent to no more than $0.1 \mathrm{~mm}$ BAPTA in altering the time constant of adaptation. Thus, when expressed in terms of an equivalent BAPTA concentration, EGTA had a differential effect on the two transducer parameters. When the EGTA concentration was reduced to $1 \mathrm{~mm}$ EGTA, the fraction of current activated at rest was equivalent to $0.1 \mathrm{~mm}$ BAPTA, but the adaptation time constant was not further accelerated and had a value similar to $10 \mathrm{~mm}$ EGTA or $0.1 \mathrm{~mm}$ BAPTA. Thus, the time constant became independent of the calcium buffer. One reason for this may be that with low buffering the time course of the $\mathrm{Ca}^{2+}$ transient is no longer the rate-limiting step in adaptation, which is now con- 

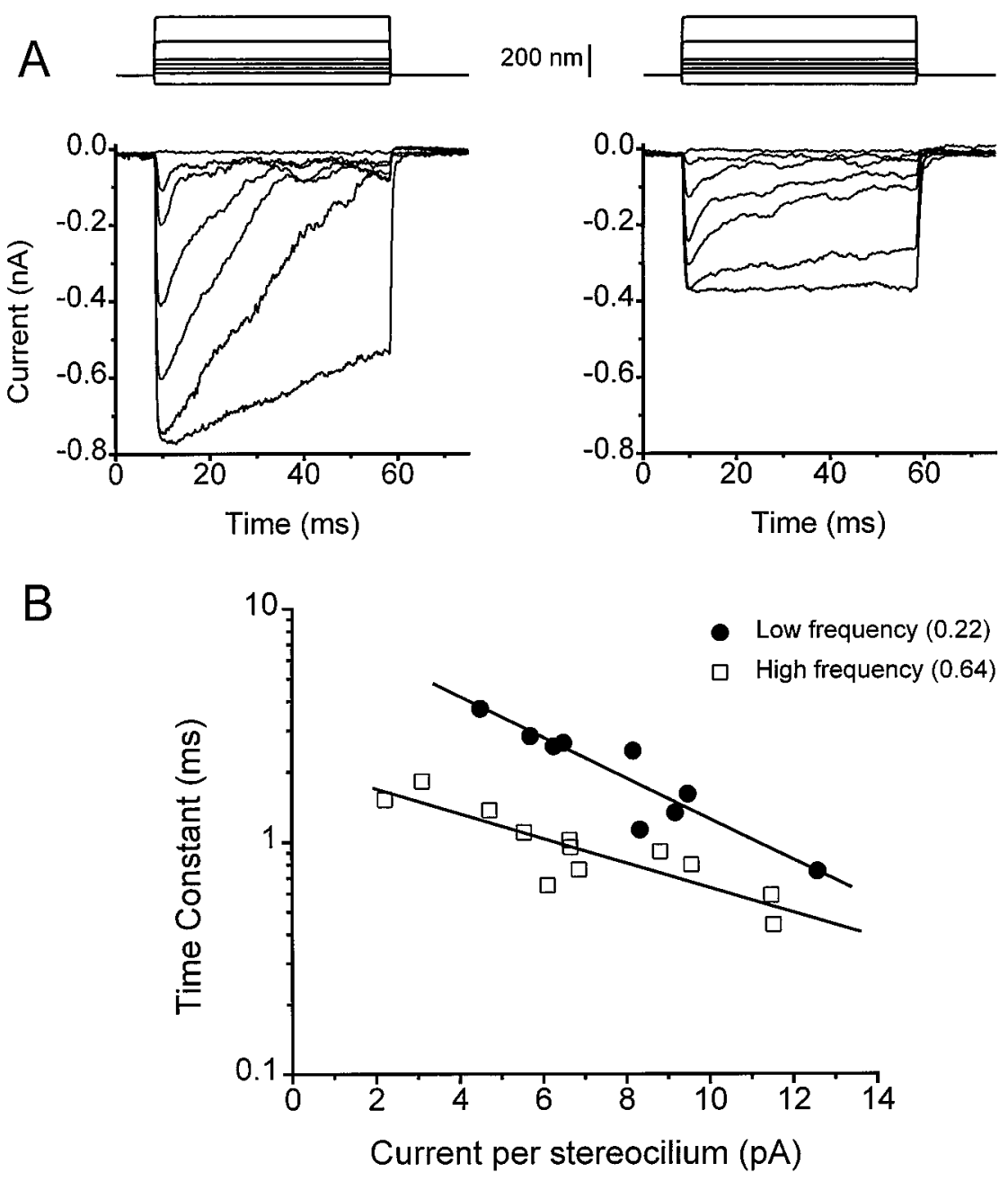

Figure 4. Effects of transducer current amplitude on the speed of adaptation. $A$, Transducer current families from different high-frequency cells showing a faster time course of adaptation in the cell with the larger current amplitude. $B$, Collected results of the adaptation time constant against maximum transducer current per stereocilium for the low-frequency location (filled symbols) and the high-frequency location (open symbols). The abscissa is the maximum current amplitude scaled by the expected number of stereocilia, 60 for the low-frequency location and 90 for the highfrequency location. The mean cell location is given as the fractional distance along the basilar membrane from the low-frequency end. Cells were selected as originating from a narrow range of positions and, to obtain a range of currents, some cells with the smallest amplitudes were included but were not used in the other analyses. All measurements correspond to 2.8 mM external $\mathrm{Ca}^{2+}$ concentration and $1 \mathrm{~mm}$ BAPTA internal buffer. The lines are least-squares fits with slopes and regression coefficients of -0.086 and 0.92 ( filled symbols) and -0.052 and 0.87 (open symbols). Note the plots for the two locations are separated and have different slopes. strained by subsequent kinetic processes. With use of exogenous buffers like BAPTA and EGTA, it is generally assumed that they exert no effect distinct from their $\mathrm{Ca}^{2+}$-binding action. The overall similarity in behavior of the transducer currents obtained with perforated-patch recordings compared with those with whole-cell recording with exogenous buffers supports this assumption. Furthermore, the peak current amplitudes were similar with different buffers. For example, maximal transducer currents in $2.8 \mathrm{mM} \mathrm{Ca}^{2+}$ were $1030 \pm 107 \mathrm{pA}, n=7$ (0.1 mM BAPTA); $942 \pm 88 \mathrm{pA}, n=7$ (10 mM BAPTA); and $1116 \pm 108 \mathrm{pA}, n=$ 10 (10 mm EGTA).

For comparison with the endogenous buffer, three other buffers with higher $\mathrm{Ca}^{2+}$ dissociation constants $\left(K_{\mathrm{Ca}}\right)$ were tested, dibromo-BAPTA $\left(K_{\mathrm{Ca}}=2 \mu \mathrm{M}\right.$; Tsien, 1980$)$, nitro-BAPTA $\left(K_{\mathrm{Ca}}\right.$ $=40 \mu \mathrm{M}$; Pethig et al., 1989), and tetrafluoro-BAPTA $\left(K_{\mathrm{Ca}}=65\right.$ $\mu \mathrm{M}$ at $37^{\circ} \mathrm{C}$; London et al., 1994). (The presence of $\mathrm{Mg}^{2+}$ in the intracellular medium may alter somewhat the values of these dissociation constants; Pethig et al., 1989.) The clearest set of data were obtained with nitro-BAPTA, which had a more pronounced effect on the adaptation time constant than on the fraction of current activated at rest (Fig. 6). The nitro-BAPTA was added to the internal solution at a concentration of 0.9 mM mixed with 0.1 mM BAPTA, the small amount of BAPTA being needed because the cells deteriorated rapidly with only a low-affinity calcium buffer. The buffer combination had effects comparable to $0.1 \mathrm{~mm}$ BAPTA alone on the fraction of current activated at rest but was at least as effective as $1 \mathrm{~mm}$ BAPTA in slowing the adaptation time constant. Results similar in direction but less extreme in magnitude were observed with dibromo-BAPTA, which was less effective than an equivalent concentration of BAPTA in reducing the fraction of current activated at rest but slightly more effective in decreasing the adaptation rate (results not shown). In nine experiments, dibromo-BAPTA was found to be equivalent to approximately one-third the equivalent BAPTA concentration in affecting the fraction of current activated at rest.

The most striking behavior was seen with the lowest affinity buffer, tetrafluoro-BAPTA, which in $70 \mu \mathrm{M}$ external $\mathrm{Ca}^{2+}$ completely abolished fast transducer adaptation without altering the fraction of current turned on at rest (Fig. 7). As with the nitroBAPTA, it was necessary to add some high-affinity buffer, here 1 mM EGTA, to prevent rapid deterioration caused by $\mathrm{Ca}^{2+}$ loading. However, the effects illustrated were never seen with EGTA alone (Fig. 5). The importance of this result with tetrafluoroBAPTA is that it demonstrates a dissociation of the two aspects of adaptation and thus, resembles the effects of treatment with calmodulin antagonists (Walker and Hudspeth, 1996). Although we have analyzed transducer adaptation in terms of the two parameters, the adaptation time constant and fraction of current activated at rest, we cannot rule out that other $\mathrm{Ca}^{2+}$-dependent processes are involved. For example, the sluggish current offsets with $0.07 \mathrm{~mm}$ external $\mathrm{Ca}^{2+}$ in Figure 7 are not accounted for by the present scheme. These offsets, reflecting a slow rate of chan- 

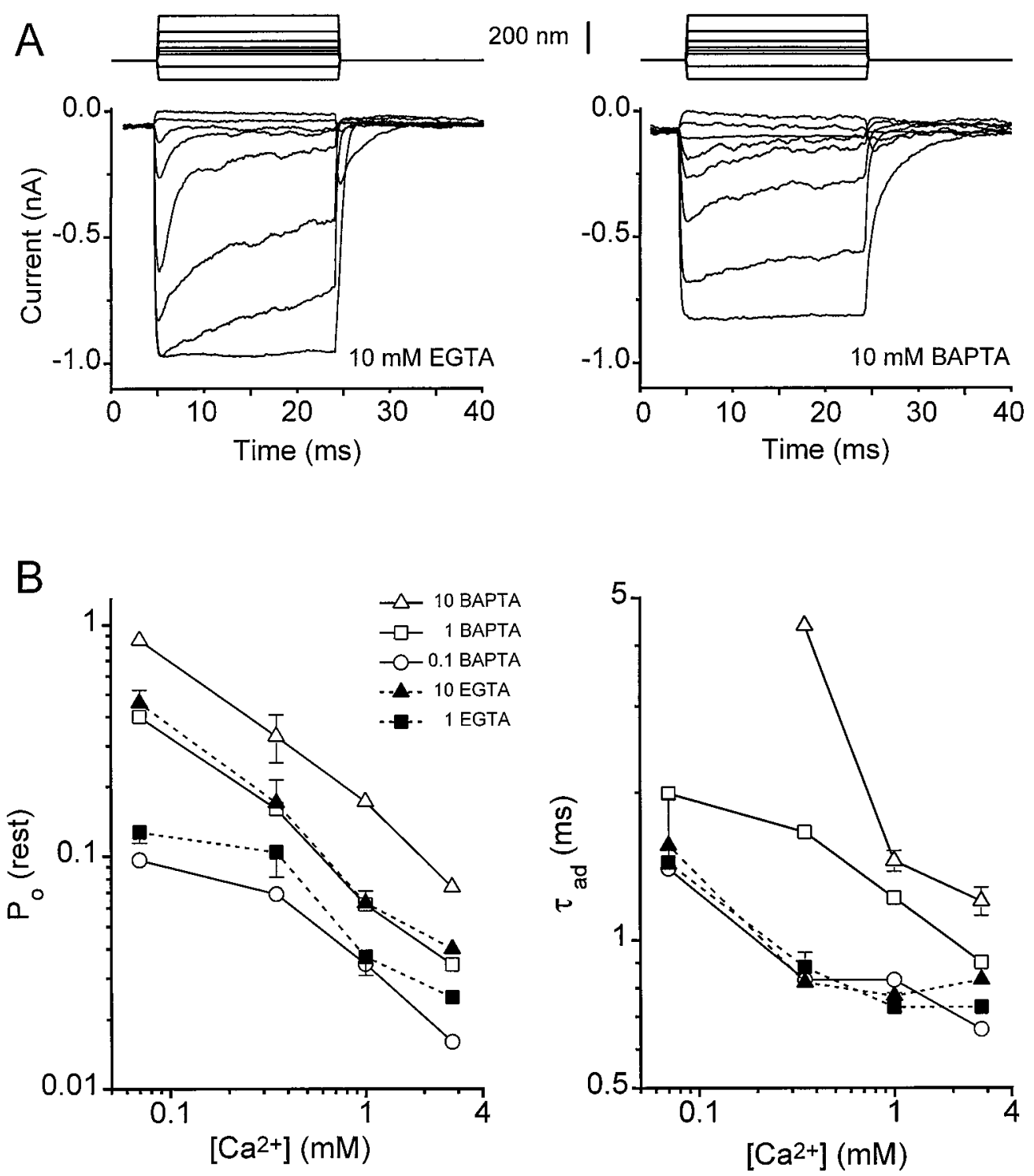

Figure 5. Comparison of the effects of EGTA and BAPTA on transducer adaptation. $A$, Families of transducer currents recorded with 10 mM EGTA and with $10 \mathrm{~mm}$ BAPTA in $2.8 \mathrm{~mm}$ external $\mathrm{Ca}^{2+}$. Note that adaptation is faster with EGTA. $B$, Collected measurements of the fraction of total current activated at rest, $P_{\mathrm{O}}$ (rest) and the time constant of adaptation, $\tau_{\mathrm{ad}}$, as a function of the external $\mathrm{Ca}^{2+}$ concentration for recordings with BAPTA (open symbols, continuous lines) and EGTA ( filled symbols, dashed lines). Note that EGTA is equivalent to a 10-fold smaller BAPTA concentration in affecting the fraction of current activated at rest but is equivalent to a 100 -fold lower BAPTA concentration in altering the adaptation time constant. Results on ten cells are presented, only one-sided SE bars being shown for clarity. Error bars for the BAPTA points are given in Figure 3.

nel closure, have been previously seen under conditions of reduced $\mathrm{Ca}^{2+}$ entry or high intracellular calcium buffer (Crawford et al., 1989).

The slow calcium buffer EGTA and the low-affinity buffers nitro-BAPTA, dibromo-BAPTA, and tetrafluoro-BAPTA all had a differential effect on the transducer parameters assayed when compared with BAPTA. This is in contrast to the behavior of the endogenous calcium buffer, which was equivalent to the same concentration of BAPTA in affecting both parameters (Fig. 3). A conclusion from these results is that the endogenous buffer must have a faster $\mathrm{Ca}^{2+}$-binding rate than EGTA and a higher affinity than any of the substituted BAPTA derivatives.

\section{$\mathbf{C a}^{2+}$ feedback and tuning of the transducer current}

To characterize adaptation, we have used the time course of relaxation of the transducer current during a sustained mechan- ical stimulus to the hair bundle. For most cells, this relaxation could be described by a single time constant. However, in a minority of recordings, the decline in the current exhibited damped oscillations (Fig. 8). Such oscillatory behavior is unlikely to be an artifact for a variety of reasons. First, the amplitude of the oscillations could be much larger than any inherent noiseinduced vibrations of the stimulating probe. For example, in Figure $8 A$ the photodiode monitor of the motion of the probe showed no hint of noise or oscillations of amplitude comparable to the relative size of the oscillations in the current response. Second, the frequency of the damped oscillations was different in different cells. In 11 cells in which oscillations were visible, their frequency ranged from 58 to $230 \mathrm{~Hz}$ (Fig. 9). Thirdly, their appearance was related to the $\mathrm{Ca}^{2+}$ balance of the cells. In Figure 8 , the oscillations become apparent when the external 
A

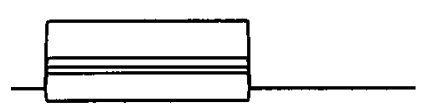

$0.07 \mathrm{mM} \mathrm{Ca}^{2+}$
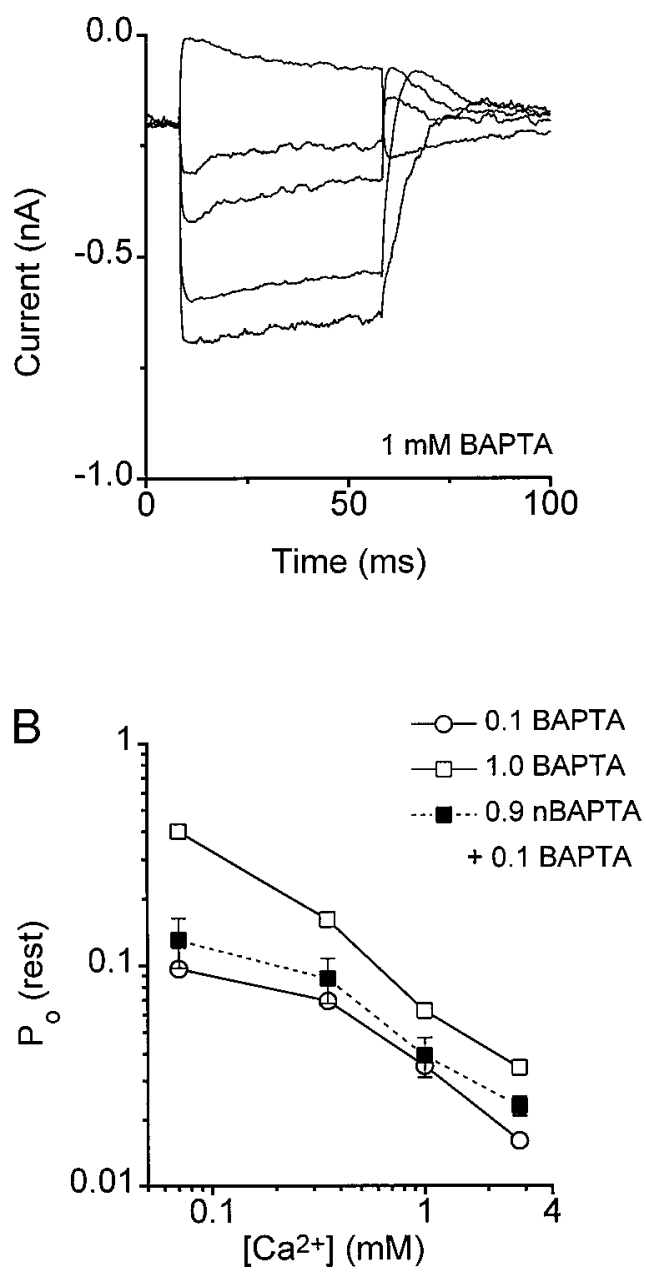

$800 \mathrm{~nm}$

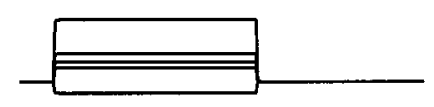

$0.07 \mathrm{mM} \mathrm{Ca}^{2+}$

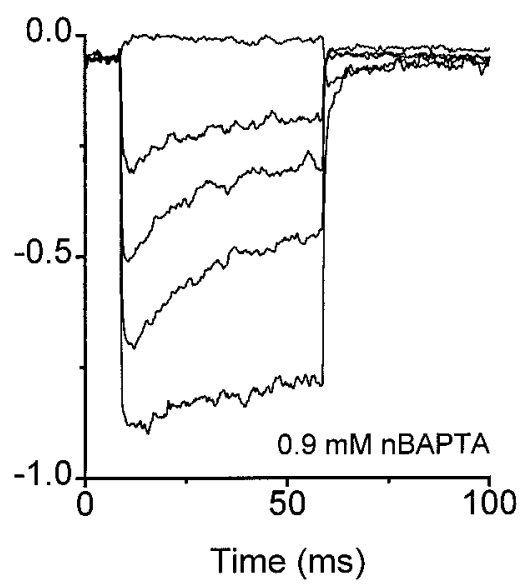

Figure 6. The effects on transducer adaptation of a low-affinity $\mathrm{Ca}^{2+}$ buffer, nitro-BAPTA, compared with BAPTA. $A$, Families of transducer currents recorded with $1 \mathrm{~mm}$ BAPTA or with $0.9 \mathrm{~mm}$ nitro-BAPTA plus $0.1 \mathrm{~mm}$ BAPTA in $0.07 \mathrm{~mm}$ external $\mathrm{Ca}^{2+}$. Note that although adaptation is slow under both conditions, a larger fraction of current is turned on at rest with the $1 \mathrm{~mm}$ BAPTA. $B$, Collected measurements of the fraction of total current activated at rest, $P_{\mathrm{O}}$ (rest), and the time constant of adaptation, $\tau_{\mathrm{ad}}$, as a function of the external $\mathrm{Ca}^{2+}$ concentration for recordings with BAPTA (open symbols, continuous lines) and 0.9 mM nitro-BAPTA plus $0.1 \mathrm{~mm}$ BAPTA ( filled symbols, dashed lines; 6 cells). Note that nitro-BAPTA is equivalent to a 10 fold smaller BAPTA concentration in affecting the fraction of current activated at rest but is at least as effective as BAPTA in altering the adaptation time constant. Measurements on six cells are included for nitro-BAPTA. Error bars for BAPTA results are shown in Figure 3.
$\mathrm{Ca}^{2+}$ was reduced from $2.8 \mathrm{~mm}$ to $70 \mu \mathrm{M}$. In the cell of Figure $8 B$, the maximum amplitude of the transducer current was virtually identical in 350 and $70 \mu \mathrm{M}$ external $\mathrm{Ca}^{2+}$, but the oscillations were much more obvious in the lower $\mathrm{Ca}^{2+}$ concentration. If the oscillations were manifestations of vibration in the stimulating probe, they should have had a similar size in both $\mathrm{Ca}^{2+}$ concentrations for which the maximum current amplitude and transducer sensitivity was comparable. When oscillations were evident at more than one $\mathrm{Ca}^{2+}$ concentration, their frequency was increased on average by $36 \%(n=3)$ in the higher $\mathrm{Ca}^{2+}(0.35$ or 1 $\mathrm{mm})$ relative to $70 \mu \mathrm{M}$. Finally, the oscillations are unlikely to result from any activation of the basolateral membrane conductances because the cells were voltage-clamped at $-90 \mathrm{mV}$ at which the voltage-dependent conductances would be completely turned off (Art and Fettiplace, 1987).

Such oscillatory recordings were difficult to study systematically because they were prominent in only a minority of recordings, usually in cells with the largest maximum responses. Nevertheless, they are important in the present context because they may reflect the true physiological performance of transduction. If this were the case they could contribute to the frequency selectivity of the hair cell and should, thus, occur at a frequency appropriate for the location of the cell. The oscillations were most conspicuous in circumstances resembling those in vivo, with $70 \mu \mathrm{M}$ external $\mathrm{Ca}^{2+}$ and with a low concentration of internal calcium buffer. Under such conditions, with $0.1 \mathrm{~mm}$ BAPTA or $1 \mathrm{~mm}$ EGTA as the buffer, the mean oscillation frequency was $115 \pm 30 \mathrm{~Hz}$ at a mean cochlear location of $0.54(n=5)$. A similar oscillation frequency of $106 \mathrm{~Hz}$ was obtained in perforated patch-patch recordings (Fig. $8 B$ ) from two cells at a cochlear location of 0.54 . Based on the tonotopic organization of the turtle cochlea, the resonant frequency corresponding to this cochlear location is $170 \mathrm{~Hz}$.

The damped oscillatory transducer currents are most likely related to the fast adaptation mechanism. Both processes are $\mathrm{Ca}^{2+}$-sensitive and have a comparable frequency range. Thus, in perforated-patch recordings the adaptation time constant, $\tau_{\mathrm{ad}}$, of $1.4 \mathrm{msec}$ (Table 1) is equivalent to a half-power frequency (= $1 / 2 \pi \tau_{\mathrm{ad}}$ ) of $114 \mathrm{~Hz}$, similar to the mean oscillation frequency of $106 \mathrm{~Hz}$. A relationship between the damped oscillatory trans- 

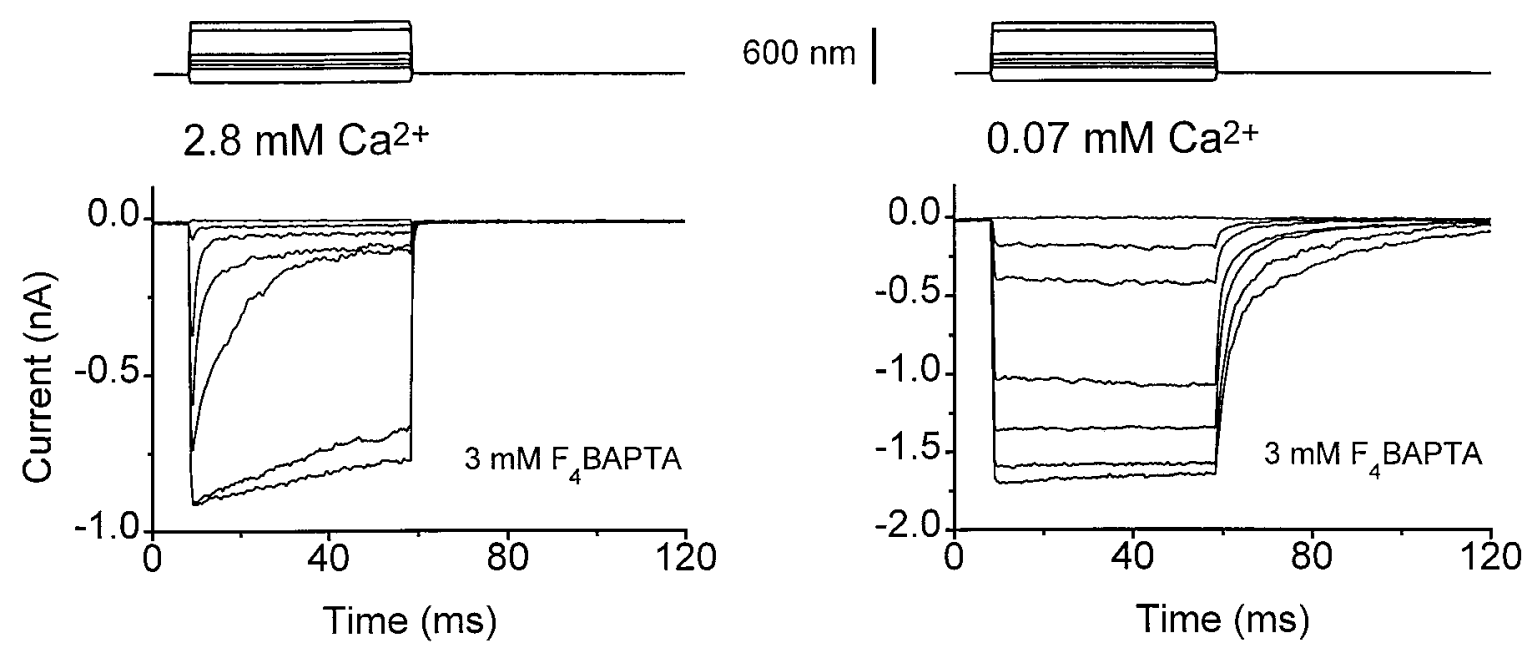

Figure 7. Families of transducer currents recorded with whole-cell patch electrodes containing 3 mM tetrafluoro-BAPTA plus 1 mM EGTA as the Ca ${ }^{2+}$ buffer. Each trace is the average of 5-25 responses. Note that in $2.8 \mathrm{mM}^{2}$ external $\mathrm{Ca}^{2+}$, the cell showed fast adaptation, which was completely abolished in $0.07 \mathrm{~mm}$ external $\mathrm{Ca}^{2+}$ with no increase in the fraction of current turned on at rest. This behavior was not seen with $1 \mathrm{~mm}$ EGTA alone (Fig. 5). Similar results were obtained in two other cells.

ducer currents and adaptation may be inferred by considering that adaptation reflects a negative feedback control of the transducer channels. $\mathrm{Ca}^{2+}$ entering through open channels triggers an intracellular process that acts to close the channels and hence reduce $\mathrm{Ca}^{2+}$ influx. Such negative feedback may be overdamped, where the response output decays exponentially with time to a steady level. It may be slightly underdamped and cause the decaying response to undershoot the steady level. However, it can also be very underdamped, in which case, the response settles with an oscillatory time course. All three types of response were observed experimentally, although the first two were most common. The underdamped oscillatory behavior is a manifestation of resonance that can produce frequency tuning for sinusoidal stimuli with the magnitude of the transducer current being maximal at the resonant frequency. The sharpness of tuning endowed by the resonance can be assessed from the quality factor or $\mathrm{Q}_{3 \mathrm{~dB}}$ value (Crawford and Fettiplace, 1981a,b) which was 2-3 for the cells in Figure 9. If such resonance behavior proves to be a physiologically significant feature of transduction, then the speed of adaptation assumes importance in determining the resonant frequency. The variation in the adaptation time constant with cochlear location suggests that, in those hair cells displaying resonance in the transducer current, there might also be a variation in resonant frequency along the cochlea.

\section{A model for the $\mathrm{Ca}^{2+}$ gradient along the stereocilia}

The fraction of current turned on at rest reflects the position of the transducer activation curve and is also subject to $\mathrm{Ca}^{2+}$ feedback. As the transducer channels open during a positive stimulus, letting in more $\mathrm{Ca}^{2+}$, the activation curve is shifted to larger bundle displacements, thus reducing the $\mathrm{Ca}^{2+}$ entry at rest (Assad et al., 1989; Crawford et al., 1989). Conversely, as the external $\mathrm{Ca}^{2+}$ is reduced, the activation curve shifts to smaller displacements so the fraction of current turned on at rest increases. The resting open probability of the transducer channels thus adjusts the entry of $\mathrm{Ca}^{2+}$ to stabilize its concentration at an internal site (Ricci and Fettiplace, 1998). Why then should the fraction of current turned on at rest depend on the concentration of calcium buffer? One explanation is that there is a gradient in $\mathrm{Ca}^{2+}$ from its source, the transducer channel, to its site of action, and the steepness of the gradient depends on the buffer concentration (Neher, 1986; Stern, 1992; Naraghi and Neher, 1997). $\mathrm{Ca}^{2+}$ gradients along the stereocilia have been measured experimentally with confocal $\mathrm{Ca}^{2+}$ imaging (Denk et al., 1995; Lumpkin and Hudspeth, 1995), but the major portion of the gradient is likely to exist within the first $100 \mathrm{~nm}$ from the channel, a distance below the resolution of current light microscopy. As an alternative, we have chosen to calculate the steady-state diffusional gradient based on assumptions about buffer properties and $\mathrm{Ca}^{2+}$ entry and extrusion processes.

The approach was identical to that described in $\mathrm{Wu}$ et al. (1996), the details of which are given in the Appendix. A threedimensional model of the stereocilium was compartmentalized in cylindrical coordinates. The major components and features of the model were as follows: (1) the transducer channels were represented as a diffuse $\mathrm{Ca}^{2+}$ source, $10 \mathrm{~nm}$ radius, located at the tip of the stereocilium (Jaramillo and Hudspeth, 1992). Additional channels placed on the side-wall of the stereocilium (Denk et al., 1995) were neglected as a first approximation because of the added complexity needed for the model. (2) The $\mathrm{Ca}^{2+}$ influx through the transducer channels was derived from the current activated at rest (Figs. 3, 5) multiplied by the fraction of the current carried by $\mathrm{Ca}^{2+}$ in different external concentrations (Ricci and Fettiplace, 1998). Because the latter $\mathrm{Ca}^{2+}$ permeability data were obtained for a high-frequency location, the simulation was confined to hair cells at this location. (3) $\mathrm{Ca}^{2+}$ was extruded via plasma membrane CaATPase pumps (Crouch and Schulte, 1995; Tucker and Fettiplace 1995) at a density of 2000/ $\mu \mathrm{m}^{2}$, a value similar to that deduced experimentally (Wu et al., 1996; Ricci and Fettiplace, 1998; Yamoah et al., 1998). (4) The components of the intracellular calcium buffering included three concentrations of BAPTA $(0.1,1$, and $10 \mathrm{~mm})$ and $1 \mathrm{~mm}$ free ATP which buffers $\mathrm{Ca}^{2+}$ close to the channel (Naraghi and Neher, 1997). If the buffering properties of ATP were not included, the $\mathrm{Ca}^{2+}$ attained a higher concentration close to the membrane, but the form of the $\mathrm{Ca}^{2+}$ profiles described below were not substantially altered. Table 2 lists values for buffer-binding constants and diffusion coefficients. 
A
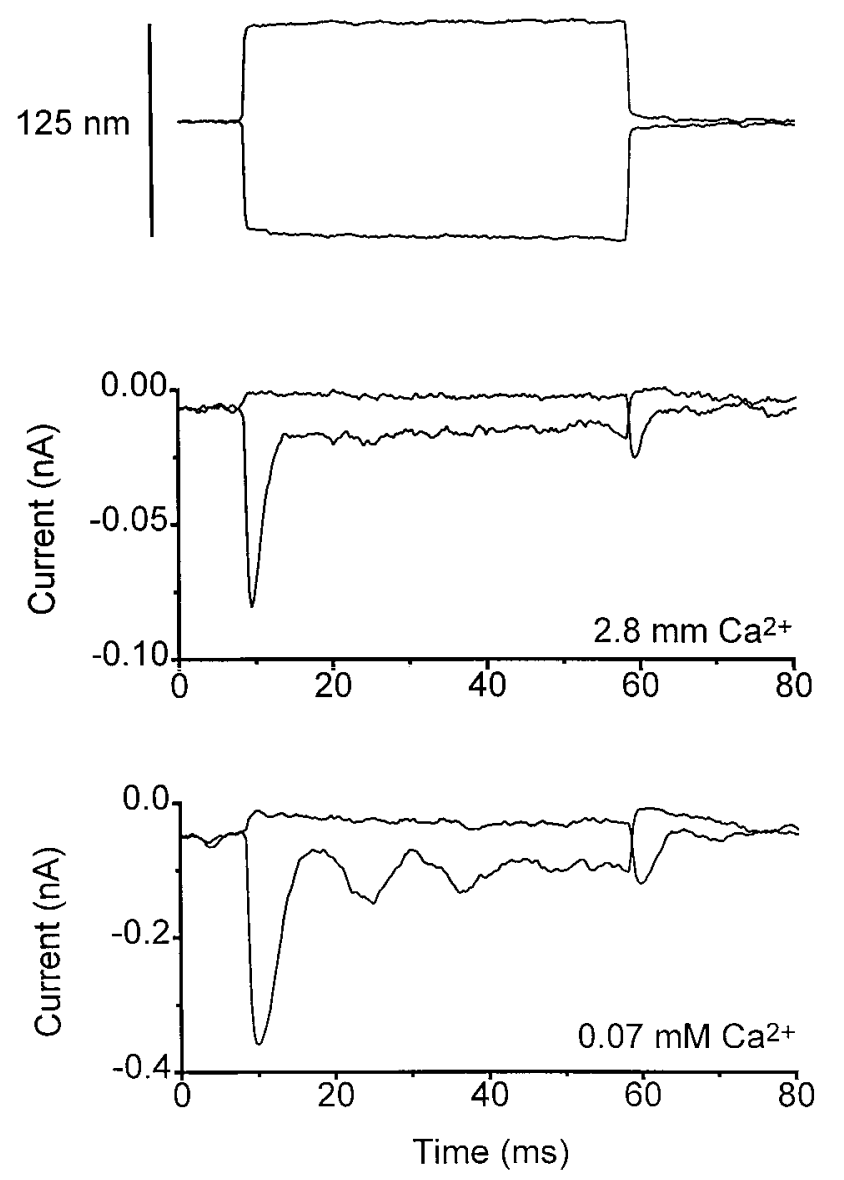

B
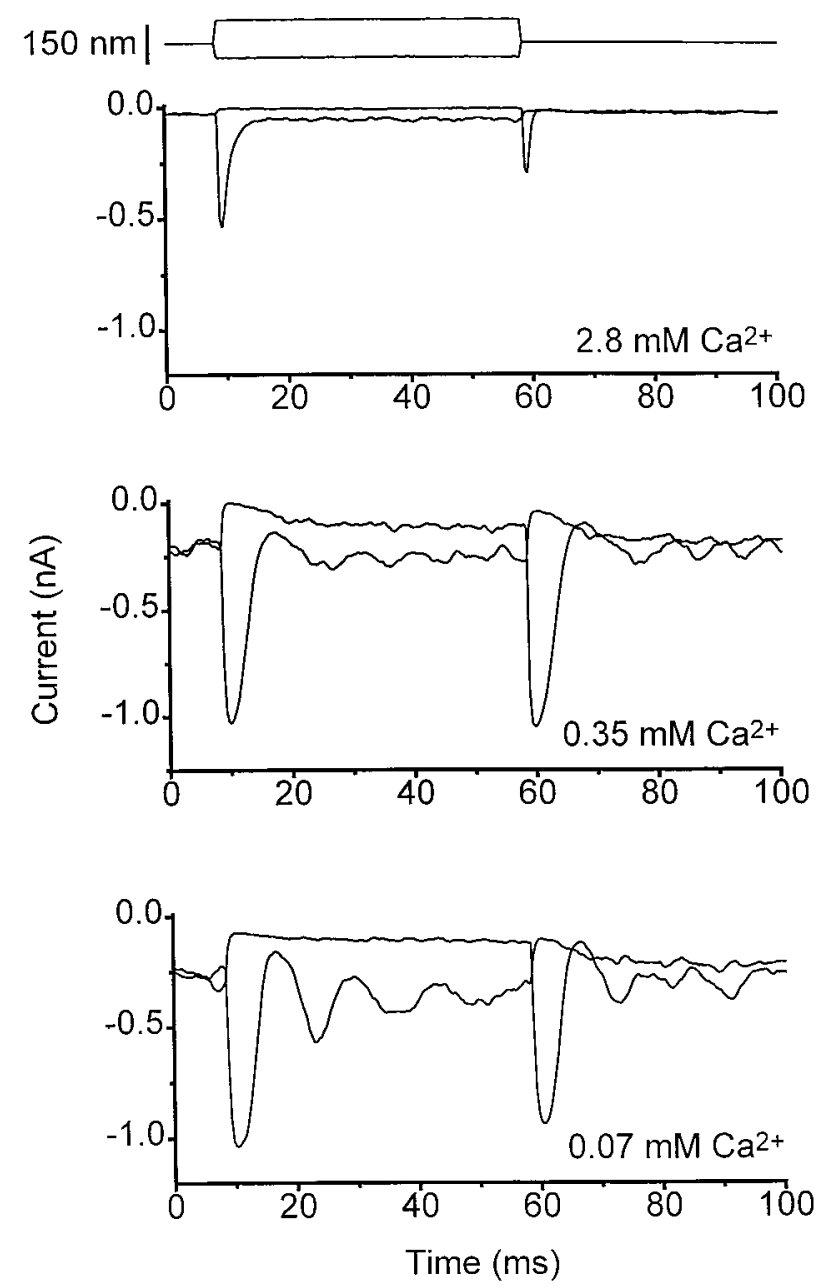

Figure 8. Damped oscillations in the transducer current response. A, Perforated-patch recording for a hair cell at the high-frequency location. When the external $\mathrm{Ca}^{2+}$ concentration was reduced from 2.8 to $0.07 \mathrm{mM}$, there was an augmentation in response amplitude and the appearance of damped oscillations for the positive steps. The time course of motion of the stimulating probe, measured with a dual photodiode detector, is given at the top and shows no hint of oscillations in the stimulus. Oscillation frequency, $82 \mathrm{~Hz}$; maximum current amplitude, $0.6 \mathrm{nA}$. $B$, Whole-cell recording with an intracellular solution buffered with $1 \mathrm{mM}$ EGTA. As in $A$, the damped oscillations are most prominent in the lowest external Ca ${ }^{2+}$ concentration. Oscillation frequencies at stimulus onset, $92 \mathrm{~Hz}\left(0.35 \mathrm{~mm} \mathrm{Ca}^{2+}\right)$ and $77 \mathrm{~Hz}\left(0.07 \mathrm{~mm} \mathrm{Ca}^{2+}\right)$; maximum current amplitude, $1.63 \mathrm{nA}$. Each record in both $A$ and $B$ is the average of 25 responses.

Figure $10 A$ gives results of the calculations illustrating the $\mathrm{Ca}^{2+}$ profile in a slice through the center of the stereociliary cylinder. Surrounding the apically placed channel is a cloud of high $\mathrm{Ca}^{2+}$, the concentration and spatial extent of which depend on the amount of BAPTA present. The gradient is shallower and the $\mathrm{Ca}^{2+}$ levels lower the smaller the BAPTA concentration. The $\mathrm{Ca}^{2+}$ profiles are plotted in Figure $10 \mathrm{~B}$ along the cylinder axis, which, at the stereociliary tip, intersects the transducer channel complex. The $\mathrm{Ca}^{2+}$ concentration near the channel increases with buffer concentration because of the fact that a greater fraction of current is turned on at rest (Fig. 3), but the $\mathrm{Ca}^{2+}$ declines more steeply the higher the buffer concentration. As a consequence, the profiles in the different buffers cross at a distance of 15-35 nm from the source and at an internal $\mathrm{Ca}^{2+}$ concentration of 10-20 $\mu \mathrm{M}$. The coordinates of the crossing point were comparable in the two external $\mathrm{Ca}^{2+}$ concentrations (Fig. $10 B)$. The form of the profiles and the location of the crossing point were not significantly affected by a 10 -fold increase in the density of CaATPase pumps or by a fivefold reduction in the buffer diffusion coefficients (data not shown).

To appreciate the significance of the crossing point, suppose that the BAPTA concentration in an unstimulated hair cell was rapidly raised from 0.1 to $10 \mathrm{~mm}$. The $\mathrm{Ca}^{2+}$ gradient with distance from the channel would initially become steeper and, with no change in the channel open probability, there would be a substantial drop in $\mathrm{Ca}^{2+}$ concentration at the internal site controlling adaptation. $\mathrm{Ca}^{2+}$ would dissociate from its binding site and promote a change in the adaptive feedback that would cause a leftward-shift in the transducer activation curve and an increase in the resting open probability of the transducer channels. As a consequence, the influx of $\mathrm{Ca}^{2+}$ would increase so as to restore its concentration at the control site. Because for small stimuli, adaptation is close to complete, at least in $2.8 \mathrm{~mm}$ external $\mathrm{Ca}^{2+}$ (Fig. 2; Ricci and Fettiplace, 1997), the crossing point may represent the locus of the $\mathrm{Ca}^{2+}$-binding site. However, in view of the assumptions involved in the calculation and the possibility that 

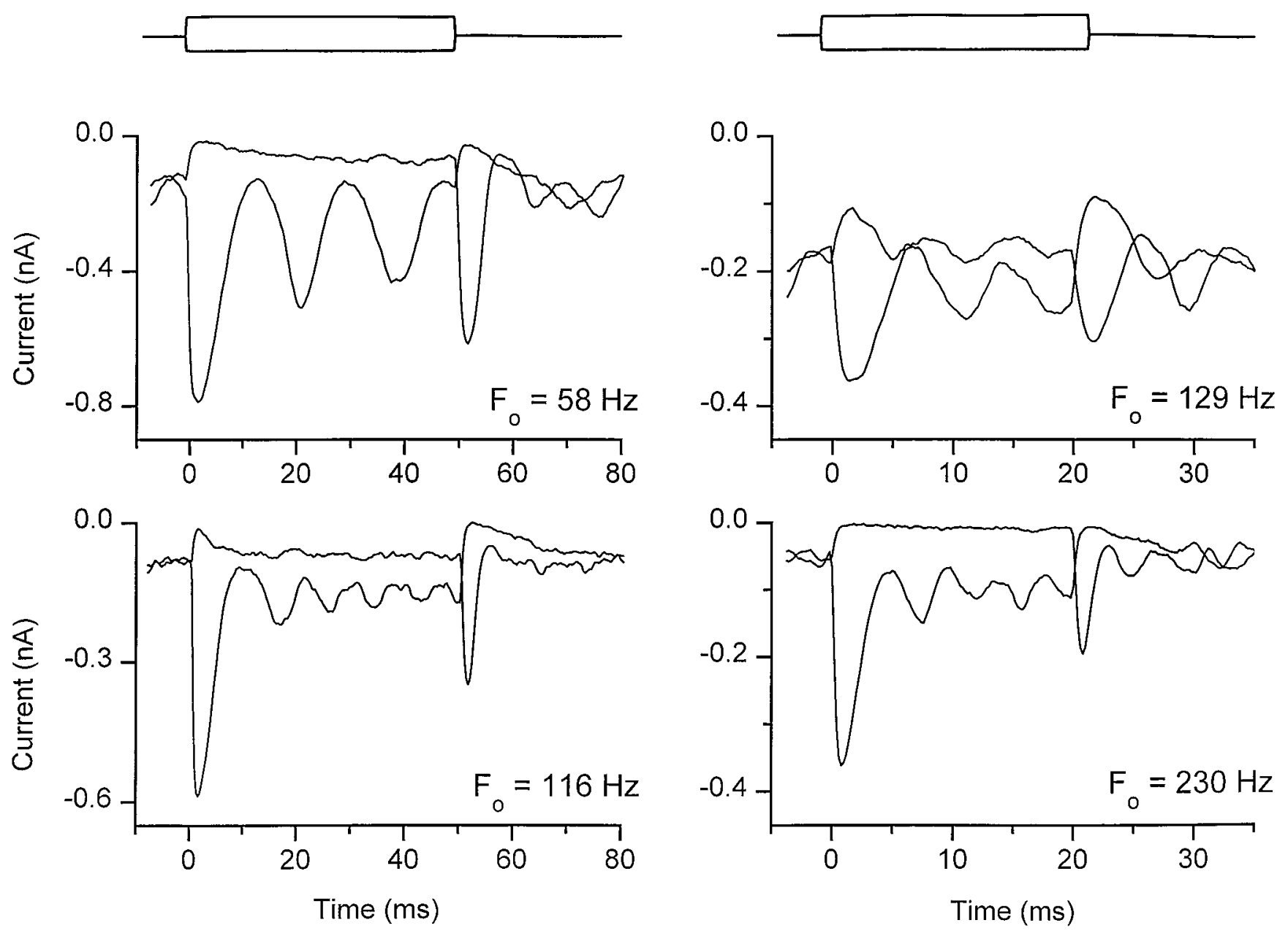

Figure 9. Damped oscillations in transducer currents illustrating the range of frequency tuning in different hair cells. Averaged currents in four cells are shown for small, $\pm 50 \mathrm{~nm}$ or $\pm 100 \mathrm{~nm}$, bundle displacements of duration $50 \mathrm{msec}$ (left) or $20 \mathrm{msec}$ (right). The timing of the stimulus is displayed above the responses, the time axis being different on the left and right. The resonant frequencies, $F_{\mathrm{O}}$, inferred from the oscillatory period for the onset of the response to positive stimuli, are denoted beside the records. The sharpness of tuning was estimated from the quality factor $\left(\mathrm{Q}_{3 \mathrm{~dB}}\right)$ calculated from $\mathrm{Q}_{3 \mathrm{~dB}}=\left(\pi F_{\mathrm{O}} \tau_{\mathrm{O}}\right)$, where $\tau_{\mathrm{O}}$ is the time constant of decay of the oscillations. The resonant frequency and $\mathrm{Q}_{3 \mathrm{~dB}}$ and the concentration of external Ca ${ }^{2+}$ and intracellular calcium buffer for the four cells were: $61 \mathrm{~Hz}, 2.8,0.07 \mathrm{~mm} \mathrm{Ca}^{2+}, 3 \mathrm{~mm} \mathrm{~F}_{4}$-BAPTA + $1 \mathrm{mM} \mathrm{EGTA;} 116 \mathrm{~Hz}, 2.1,0.35 \mathrm{~mm} \mathrm{Ca}{ }^{2+}, 1 \mathrm{~mm}$ EGTA; $129 \mathrm{~Hz}, 2.8,0.35 \mathrm{~mm} \mathrm{Ca}^{2+}, 3 \mathrm{~mm}$ BAPTA; $230 \mathrm{~Hz}, 2.3,2.8 \mathrm{~mm} \mathrm{Ca}^{2+}, 1 \mathrm{~mm}$ BAPTA.

the binding sites are spatially distributed, we do not wish to place too much emphasis on the absolute coordinates. Nevertheless, the intersection of the $\mathrm{Ca}^{2+}$ profiles in different calcium buffers is consistent with intracellular $\mathrm{Ca}^{2+}$-mediating feedback regulation of the transducer channels. Furthermore, a change in the steepness of the $\mathrm{Ca}^{2+}$ profile in different buffer concentrations provides a rational explanation for the effect of the buffer on the position of the transducer activation curve.

\section{Equivalent calbindin concentration}

The level of endogenous buffer ascertained from the perforatedpatch recordings has been expressed in terms of an effective concentration of BAPTA. The endogenous buffer is probably a protein like calbindin or parvalbumin with a smaller diffusion coefficient and different $\mathrm{Ca}^{2+}$-binding properties than BAPTA. We used the $\mathrm{Ca}^{2+}$ diff usion model to estimate the concentration of calbindin $28 \mathrm{k}$ that would produce the same $\mathrm{Ca}^{2+}$ profile as BAPTA. A fixed $\mathrm{Ca}^{2+}$ entry, corresponding to that in perforated-patch recordings in $2.8 \mathrm{~mm}$ external $\mathrm{Ca}^{2+}$, was assumed, and $\mathrm{Ca}^{2+}$ profiles in a series of BAPTA concentrations were matched to those in different calbindin concentrations. Cal- bindin was assumed to have a fourfold smaller diffusion coefficient than BAPTA, approximated from the cube root of the ratio of molecular weights. This gives a diffusion coefficient of $50 \mu \mathrm{m}^{2}$ $\mathrm{sec}^{-1}$, which is comparable to the value of $75 \mu \mathrm{m}^{2} \mathrm{sec}^{-1}$ estimated for the endogenous buffer in saccular hair cells by Hall et al. (1997). Because the $\mathrm{Ca}^{2+}$-binding parameters for calbindin $28 \mathrm{k}$ are not well established, values for calbindin $9 \mathrm{k}$ were assumed (Martin et al., 1990): a $\mathrm{Ca}^{2+}$ dissociation constant of $0.5 \mu \mathrm{M}$ and a forward rate constant of $20 \mu \mathrm{M}^{-1} \mathrm{sec}^{-1}$. As shown in Figure 11, over most of the $\mathrm{Ca}^{2+}$ range, a given BAPTA concentration could be reasonably matched with an $\sim 20$-fold larger calbindin concentration. The match deteriorated at low $\mathrm{Ca}^{2+}$ concentrations for distances $>100 \mathrm{~nm}$ from the channel. Thus, the range of BAPTA concentrations equivalent to the native buffer $(0.1-0.4$ $\mathrm{mM}$ ) would correspond to $2-8 \mathrm{~mm}$ calbindin $\mathrm{Ca}^{2+}$-binding sites, or $0.5-2 \mathrm{~mm}$ calbindin, assuming four $\mathrm{Ca}^{2+}$-binding sites per molecule (Bredderman and Wasserman, 1974). A similarly high concentration of calbindin $28 \mathrm{k}, \sim 1 \mathrm{~mm}$, has been found in the chick basilar papilla (Oberholtzer et al., 1988) and has been estimated for frog saccular hair cells (Roberts, 1994). 


\begin{tabular}{|c|c|c|}
\hline Symbol & Definition & Value \\
\hline$k_{\mathrm{D}}^{+} \mathrm{BAPTA}$ & $\begin{array}{c}\text { Rate constant for } \mathrm{Ca}^{2+} \\
\text { binding to BAPTA }\end{array}$ & $500 \mu \mathrm{M}^{-1} \sec ^{-1}$ \\
\hline$k_{\mathrm{D}}^{+}$calbindin $28 \mathrm{k}$ & $\begin{array}{l}\text { Rate constant for } \mathrm{Ca}^{2+} \\
\text { binding to calbindin } \\
28 \mathrm{~K}\end{array}$ & $20 \mu \mathrm{M}^{-1} \mathrm{sec}^{-1}$ \\
\hline$k_{\mathrm{D}}^{+}$ATP & $\begin{array}{l}\text { Rate constant for } \mathrm{Ca}^{2+} \\
\text { binding to ATP }\end{array}$ & $500 \mu \mathrm{M}^{-1} \sec ^{-1}$ \\
\hline$\left[\mathrm{B}_{\mathrm{D}}^{\mathrm{T}}\right]$ & $\begin{array}{l}\text { Total concentration of } \\
\text { diff usible buffer }\end{array}$ & $10,0.1,1 \mathrm{mM}$ \\
\hline$\left[\mathrm{B}_{\mathrm{D}}^{\mathrm{T}}\right] \mathrm{ATP}$ & $\begin{array}{l}\text { Total concentration of } \\
\text { ATP }\end{array}$ & $1 \mathrm{mM}$ \\
\hline$k_{\mathrm{D}}^{\mathrm{d}}$ BAPTA & $\begin{array}{l}\text { Dissociation constant } \\
\text { for BAPTA }\end{array}$ & $0.2 \mu \mathrm{M}$ \\
\hline$k_{\mathrm{D}}^{\mathrm{d}}$ calbindin $28 \mathrm{k}$ & $\begin{array}{l}\text { Dissociation constant } \\
\text { for calbindin } 28 \mathrm{~K}\end{array}$ & $0.5 \mu \mathrm{M}$ \\
\hline$k_{\mathrm{D}}^{\mathrm{d}}$ ATP & $\begin{array}{l}\text { Dissociation constant } \\
\text { for ATP }\end{array}$ & $2300 \mu \mathrm{M}$ \\
\hline$D_{\mathrm{Ca}}$ & $\begin{array}{l}\text { Diffusion coefficient of } \\
\text { free } \mathrm{Ca}^{2+} \text { ions }\end{array}$ & $400 \mu \mathrm{m}^{2} \mathrm{sec}^{-1}$ \\
\hline$D_{\text {B }}$ BАРТА & $\begin{array}{l}\text { Diff usion coefficient for } \\
\text { BAPTA }\end{array}$ & $200 \mu \mathrm{m}^{2} \mathrm{sec}^{-1}$ \\
\hline$D_{\mathrm{B}}$ calbindin $28 \mathrm{k}$ & $\begin{array}{l}\text { Diffusion coefficient for } \\
\text { calbindin } 28 \mathrm{~K}\end{array}$ & $50 \mu \mathrm{m}^{2} \mathrm{sec}^{-1}$ \\
\hline$D_{\mathrm{B}}$ ATP & $\begin{array}{l}\text { Diffusion coefficient for } \\
\text { ATP }\end{array}$ & $220 \mu \mathrm{m}^{2} \mathrm{sec}^{-1}$ \\
\hline
\end{tabular}

The sources of most of the values are given in Wu et al. (1996). The values for ATP are given in Naraghi and Neher (1997), and the $\mathrm{Ca}^{2+}$-binding constants for calbindin 28K are those determined for calbindin 9K (Martin et al., 1990).

\section{DISCUSSION}

\section{The concentration of endogenous diffusible buffer}

The main aim of the work was to estimate the concentration of the diff usible calcium buffer of the hair cell, which was found to have effects similar to $0.1 \mathrm{~mm}$ BAPTA in low-frequency hair cells and $0.4 \mathrm{~mm}$ BAPTA in high-frequency cells. Because the properties of the mechanoelectrical transducer current were used to assay the efficacy of the buffer, the concentration measured will largely reflect that in the hair bundle where the transducer channels are localized (Hudspeth, 1982; Jaramillo and Hudspeth, 1992). The buffer concentrations are less than the 1 mм BAPTA determined for turtle hair cells from a midcochlear region using measurements of $\mathrm{Ca}^{2+}$-activated $\mathrm{K}^{+}$channels found in the cell body (Tucker and Fettiplace, 1996).

Hair cells of both the mammalian cochlea (Pack and Slepecky, 1995) and the bullfrog vestibular organs (Shepherd et al., 1989; Baird et al., 1997) contain various calcium-binding proteins revealed with immunohistological methods. Some such proteins, calbindin, calretinin, or parvalbumin, display both a differential localization within the cell and a regional gradient across the organ. It is not difficult to imagine that if distinct types of buffer exist in the hair bundle and cell body, they may have different $\mathrm{Ca}^{2+}$-binding rates and dissociation constants and, thus, a differential efficacy relative to BAPTA. In the mammalian cochlea, there is a regional gradient in calbindin, with the highest concentration in apical low-frequency hair cells (Pack and Slepecky, 1995). The opposite distribution is suggested in the chick cochlea, in which the calbindin $28 \mathrm{k}$ transcript is more concentrated in the basal high-frequency half (Navaratnam et al., 1995). The latter observation accords with the functional gradients of calcium buffering inferred from the present results in the turtle.

\section{The time course of transducer adaptation}

A second experimental aim was to document the properties of transduction in different regions and, by using perforated-patch recordings, to obtain evidence about the transducer gradients that may exist in the intact cochlea. The values given (Table 1) were measured in an external solution containing $70 \mu \mathrm{M} \mathrm{Ca}^{2+}$ similar to the concentration in turtle endolymph that bathes the hair bundles in vivo (Crawford et al., 1991). The maximum amplitude of the transducer current was $60 \%$ larger, and the time constant of adaptation, $\tau_{\mathrm{ad}}$, was faster at the high-frequency position. The differences in $\tau_{\mathrm{ad}}, 1.4 \mathrm{msec}$ at the high-frequency location and 2.5 msec at the low-frequency location, suggest that adaptation contributes a high-pass filter to the frequency-tuning curve of the hair cell. The two mean values of $\tau_{\text {ad }}$ correspond to corner frequencies $\left(=1 / 2 \pi \cdot \tau_{\text {ad }}\right)$ of 114 and $64 \mathrm{~Hz}$, which are $\sim 0.65$ of the characteristic frequency of the cell, 90 and $200 \mathrm{~Hz}$ at the two cochlear locations.

The observation that, in some cells, the transducer current displayed resonance-like behavior at a frequency comparable to the characteristic frequency of the cell, reinforces the notion that adaptation will contribute to the frequency selectivity of the hair cell. Thus, the frequency tuning of turtle auditory hair cells is determined both by filtering imposed by the mechanoelectrical transduction process and by the electrical resonance caused by voltage-dependent conductances in the basolateral membrane (Fettiplace and Crawford, 1978; Crawford and Fettiplace, 1981b). The present experiments did not examine whether there was any mechanical correlate of the oscillatory transducer currents. Damped oscillations in bundle motion at frequencies of 20-320 $\mathrm{Hz}$ have previously been seen in turtle cochlear hair cells (Crawford and Fettiplace, 1985), and fast $\mathrm{Ca}^{2+}$-dependent oscillations at frequencies of $\sim 100 \mathrm{~Hz}$ have recently been reported in frog saccular hair bundles (Benser et al., 1996). It is possible that such bundle movements reflect mechanical changes that could underlie the transducer current oscillations reported here.

There were two anomalies in the perforated-patch recordings executed in $70 \mu \mathrm{M}$ external $\mathrm{Ca}^{2+}$. First, the fraction of transducer current activated at rest at both cochlear locations was $28 \%$, somewhat larger than the 10-15\% estimated in the intact organ (Crawford and Fettiplace, 1981a). Second, in some of the lowfrequency cells, transducer adaptation was abolished in low external $\mathrm{Ca}^{2+}$. Several experimental factors that would each reduce the $\mathrm{Ca}^{2+}$ influx may account for these anomalies. First, the maximum amplitude of the transducer currents may have been smaller than those in vivo, because of damage to the transduction apparatus during dissection. Second, the external solution, unlike endolymph, did not contain $\mathrm{K}^{+}$as the major monovalent cation; the presence of high $\mathrm{K}^{+}$has been shown to augment the fraction of $\mathrm{Ca}^{2+}$ carried by the transducer current (Ricci and Fettiplace, 1998). Third, it has been estimated for the frog saccular hair cells that $\mathrm{Ca}^{2+}$ extrusion from the hair bundle may raise the local $\mathrm{Ca}^{2+}$ concentration above that in the bulk endolymph (Yamoah et al., 1998). The calculation was based on $\mathrm{Ca}^{2+}$ entry through voltage-sensitive $\mathrm{Ca}^{2+}$ channels in the basolateral membrane and ignored the contribution of CaATPases in the cell soma. Nevertheless, it is conceivable that the $\mathrm{Ca}^{2+}$ concentration around the hair bundle may be somewhat higher than the $70 \mu \mathrm{M}$ used here to assess the physiological performance of transduction. Correction for these disparate experimental factors may bring the fraction of 
A

10 mM BAPTA

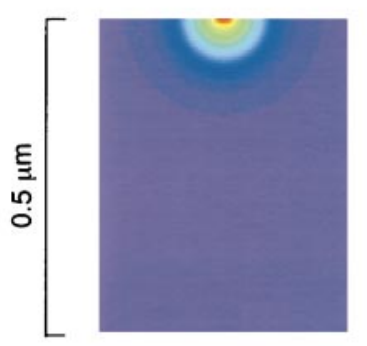

$\left[\mathrm{Ca}^{2+}\right]_{\mathrm{ex}}=0.07 \mathrm{mM}$

1 mM BAPTA

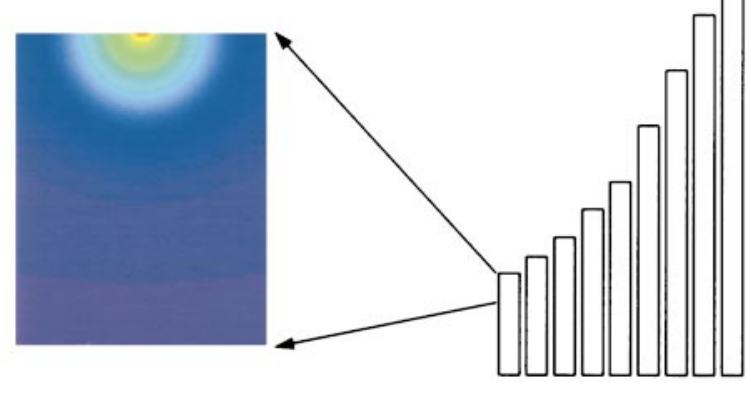

$0.1 \mathrm{mM}$ BAPTA

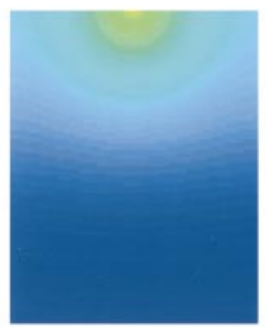

B
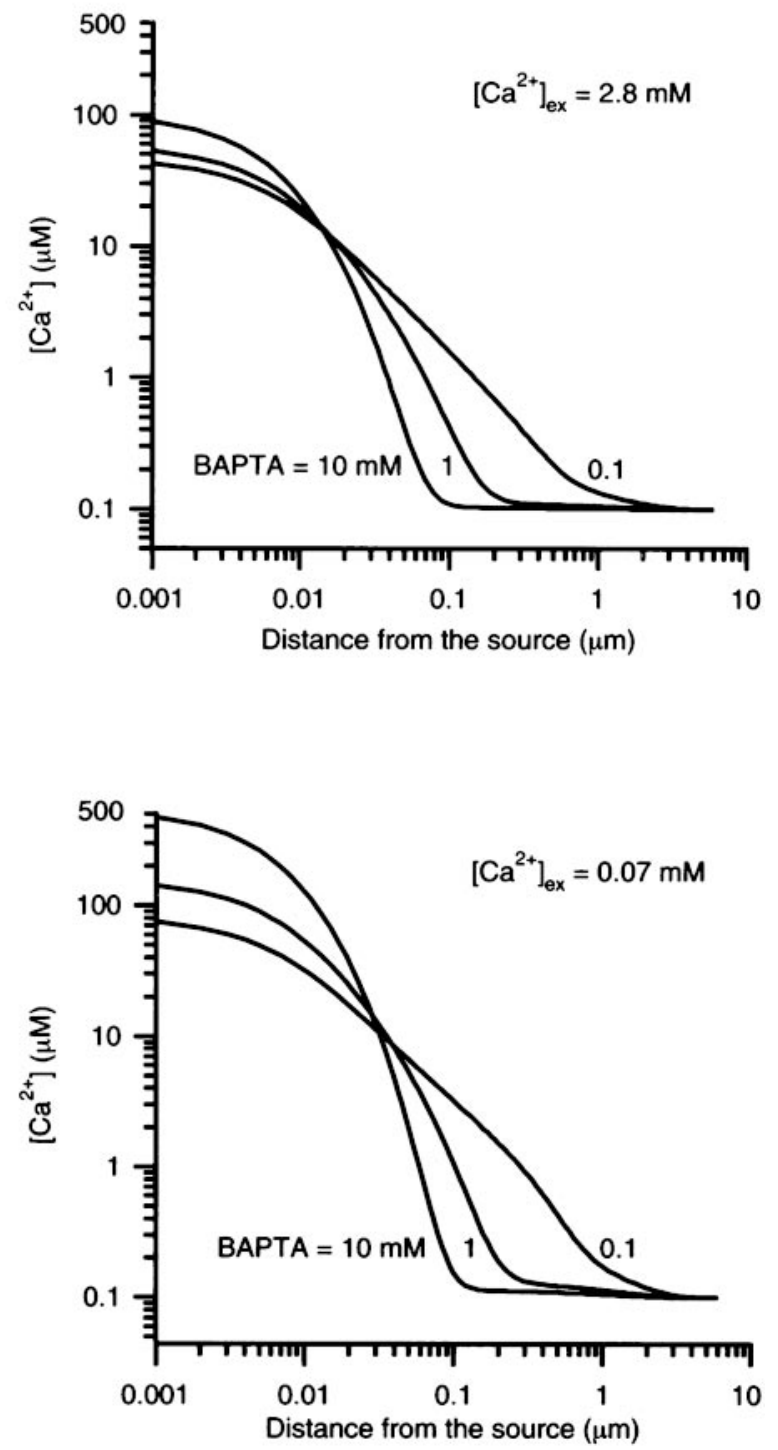

Figure 10. Steady-state $\mathrm{Ca}^{2+}$ profiles in a hair cell stereocilium predicted from a three-dimensional diffusion model. $A$, Vertical section through the center of a cylindrical stereocilium, diameter $0.4 \mu \mathrm{m}$, with a $\mathrm{Ca}^{2+}$ source, the transducer channels, placed at the distal tip. Pseudocolor images of the $\mathrm{Ca}^{2+}$ concentration profiles are shown for three different intracellular BAPTA concentrations. The $\mathrm{Ca}^{2+}$ entry was calculated from experimental data of the standing transducer current and the channel permeability in $0.07 \mathrm{~mm}$ external $\mathrm{Ca}^{2+}$. Note the $\mathrm{Ca}^{2+}$ gradient is steepest for the highest buffer concentration. $B, \mathrm{Ca}^{2+}$ profiles down the axis of the cylindrical stereocilium, length $6 \mu \mathrm{m}$, for the three BAPTA concentrations in $2.8 \mathrm{mM}$ external $\mathrm{Ca}{ }^{2+}$ (top) and $0.07 \mathrm{~mm}$ external $\mathrm{Ca}^{2+}$ (bottom). Note that the curves for the different buffers cross at a distance of $20-40 \mathrm{~nm}$ from the source.

transducer current turned on at rest into line with the values in the intact cochlea. It would also shorten the adaptation time constants, thus making the corner frequencies calculated above nearer to the characteristic frequency of the cell.

\section{One or two $\mathrm{Ca}^{2+}$-binding sites?}

Our results both on the transducer current oscillations and the $\mathrm{Ca}^{2+}$ profiles in the presence of different buffers, support the notion of a calcium-feedback regulation of the transducer channel (Ricci and Fettiplace, 1998). Two experimental manifestations of this regulation are the $\mathrm{Ca}^{2+}$ dependence of the adaptation time constant $\left(\tau_{\mathrm{ad}}\right)$ and of the fraction of transducer current activated at rest $\left(P_{\mathrm{O}}\right)$. Both parameters are sensitive to intracellular calcium buffering. An increase in buffer concentration will slow $\tau_{\text {ad }}$ by reducing the rate of change of intracellular $\mathrm{Ca}^{2+}$. It will also alter $P_{\mathrm{O}}$ by steepening the steady-state $\mathrm{Ca}^{2+}$ gradient in the stereocilium (Fig. 10); the more abrupt the decline in $\mathrm{Ca}^{2+}$ with distance from the channel, the higher the $\mathrm{Ca}^{2+}$ entry, and hence $P_{\mathrm{O}}$, must be to keep the $\mathrm{Ca}^{2+}$ level constant at the regulation site. Surprisingly, $P_{\mathrm{O}}$ and $\tau_{\mathrm{ad}}$ were differentially sensitive to other calcium buffers compared with BAPTA. EGTA had a stronger influence on $P_{\mathrm{O}}$, whereas the low-affinity buffer, nitro-BAPTA, was more effective in slowing $\tau_{\mathrm{ad}}$.

According to a recent analysis (Naraghi and Neher, 1997), a buffer can be assigned a characteristic length-constant of action determined by: (1) its mobility, which will be similar for all the BAPTA-type buffers considered; (2) its buffering power, which is related to its concentration and $K_{\mathrm{Ca}}$; and (3) its mean time to capture a $\mathrm{Ca}^{2+}$ ion, given by $\left(k_{+}[B]\right)^{-1}$, where $k_{+}$is the forward 
A

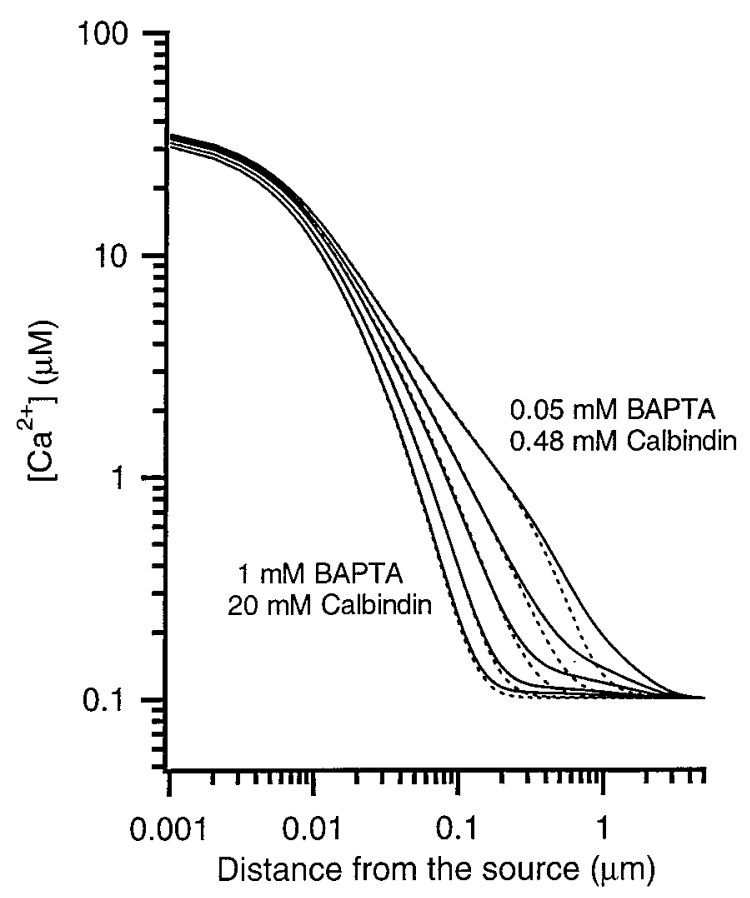

B

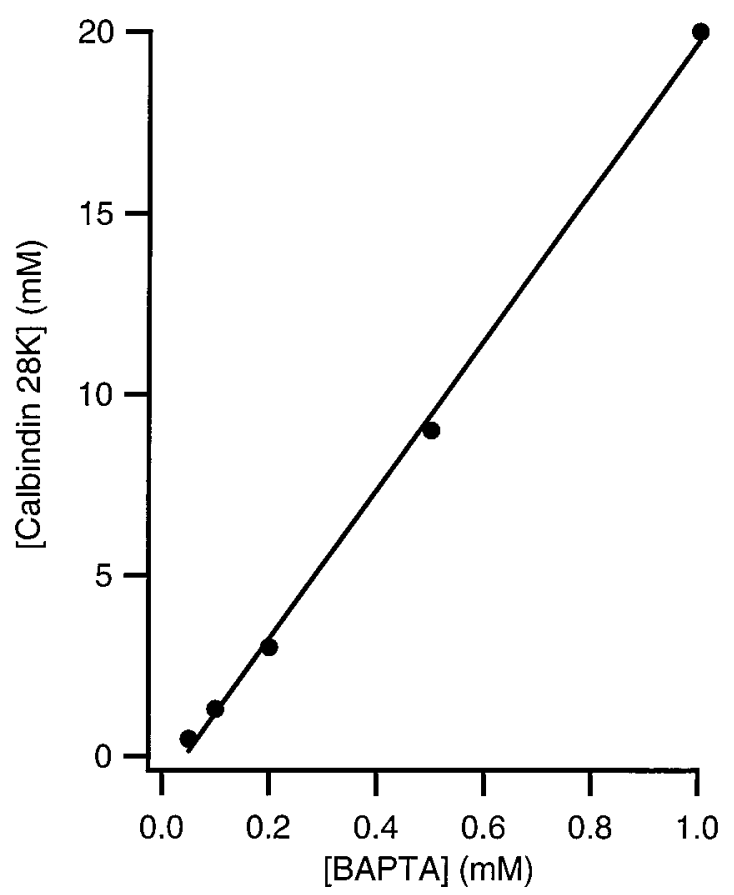

Figure 11. Relative $\mathrm{Ca}^{2+}$ profiles in the stereocilium for different concentrations of BAPTA and calbindin $28 \mathrm{k}$. A fixed Ca ${ }^{2+}$ entry, corresponding to the standing current in perforated-patch recordings in $2.8 \mathrm{mM}$ external $\mathrm{Ca}^{2+}$ was assumed in all calculations, and the concentrations of calbindin-yielding profiles (dashed lines) that matched the profiles for a range of BAPTA concentration (continuous lines) were determined. The match was optimized for $\mathrm{a} \mathrm{Ca}^{2+}$ concentration range from 1 to $20 \mu \mathrm{M}$. B. Plot of the calbindin concentrations producing equivalent profiles to those of $0.05,0.1,0.2,0.5$, and 1.0 mM BAPTA. Slope of line $=20.8$.

rate constant of the buffer and $[B]$ its concentration. EGTA, with a $k_{+} 150$-fold smaller than BAPTA, should be a less efficient $\mathrm{Ca}^{2+}$ buffer close to the source. EGTA was at least 100 times less effective, on a concentration basis, than BAPTA in affecting $\tau_{\text {ad }}$, but was only 10 -fold worse in influencing $P_{\mathrm{O}}$ (Fig. 5). In contrast, nitro-BAPTA, with a 200-fold lower affinity, and hence lower buffering power, will have a shorter length-constant than BAPTA. Nitro-BAPTA was equal to BAPTA in altering $\tau_{\text {ad }}$, but about fourfold less effective in altering $P_{\mathrm{O}}$ (Fig. 6). These combined observations suggest that the $\mathrm{Ca}^{2+}$-binding site for controlling $P_{\mathrm{O}}$ lies further from the transducer channel than the site for regulating $\tau_{\text {ad }}$. Both sites are susceptible to $1 \mathrm{~mm}$ BAPTA and must, therefore, be within $100 \mathrm{~nm}$ of the channel.

An explanation for the results is that adaptation is controlled by at least two $\mathrm{Ca}^{2+}$-binding sites. Although both sites may contribute to both transducer parameters, the differential actions of the buffers reflect the relative strengths of the sites in modulating $P_{\mathrm{O}}$ and $\tau_{\mathrm{ad}}$. Thus, nitro-BAPTA will predominantly affect $\tau_{\text {ad }}$ at a site close to the channel, whereas EGTA will mainly influence $P_{\mathrm{O}}$ at a more distant site. Some support for this hypothesis is derived from other experimental manipulations that preferentially affect one or other property of adaptation. Calmodulin antagonists abolished fast transducer adaptation with no effect on $P_{\mathrm{O}}$ (Walker and Hudspeth, 1996) and produced responses resembling those in Figure 7. In contrast, large shifts in the currentdisplacement relation with no effect on $\tau_{\text {ad }}$ were seen after treatment with phosphate analogs like vanadate (Yamoah and Gillespie, 1996) and with 8-bromo-cAMP (Ricci and Fettiplace, 1997). Whatever the mode of action of these various agents, their effects endorse the notion implied by the calcium buffer results that the two transducer parameters, $P_{\mathrm{O}}$ and $\tau_{\mathrm{ad}}$, can be manipulated independently.

\section{APPENDIX}

The stereocilium, radius $(a)=0.2 \mu \mathrm{m}$ and length $(L)=6 \mu \mathrm{m}$, was represented by a three-dimensional model compartmentalized in cylindrical coordinates $(r, \theta, z) . \mathrm{Ca}^{2+}$ enters through transducer channels located in the center of the top of the stereocilium, and fixed and diffusible buffers are initially distributed uniformly within the cytoplasmic space. Diff usion throughout the cytoplasm can be described in cylindrical coordinates as follows:

$$
\left[\frac{\partial u}{\partial t}\right]_{\text {dif usion }}=D_{\mathrm{u}} \cdot \nabla^{2} u=D_{\mathrm{u}} \cdot\left\{\frac{1}{r} \cdot \frac{\partial}{\partial r}\left(r \cdot \frac{\partial u}{\partial r}\right)+\frac{\partial^{2} u}{\partial z^{2}}\right\}
$$

with $u$ the concentration of free $\mathrm{Ca}^{2+}$ ions, $\mathrm{Ca}^{2+}$-bound or $\mathrm{Ca}^{2+}$-free diff usible buffer, and $D_{\mathrm{u}}$ the diff usion coefficient of the substance U.

\section{$\mathrm{Ca}^{2+}$ fluxes}

The averaged $\mathrm{Ca}^{2+}$ current per stereocilium is obtained from:

$$
\bar{i}_{\mathrm{Ca}}=\frac{I_{\mathrm{MT}} \cdot p_{\mathrm{Ca}}}{n_{\mathrm{s}}}=i_{\mathrm{MT}} \cdot p_{\mathrm{Ca}},
$$

where $I_{\mathrm{MT}}$ is the maximal transducer current (taken from mean experimental values), $i_{\mathrm{MT}}$ is the maximal transducer current per stereocilium, $\mathrm{p}_{\mathrm{Ca}}$ is the $\mathrm{Ca}^{2+}$ permeability, and $n_{\mathrm{s}}$ is the total 
number of stereocilia $\left(n_{\mathrm{s}}=90\right)$. Calculations were performed for two external $\mathrm{Ca}^{2+}$ concentrations in which the values of $I_{\mathrm{MT}}$, $i_{\mathrm{MT}}$, and $p_{\mathrm{Ca}}$ were: $2.8 \mathrm{mM} \mathrm{Ca}^{2+}, 700 \mathrm{pA}, 7.8 \mathrm{pA}, 0.58 ; 0.07 \mathrm{mM}$ $\mathrm{Ca}^{2+}, 1075 \mathrm{pA}, 11.9 \mathrm{pA}, 0.17$ (Ricci and Fettiplace, 1998).

The rate of change of free $\mathrm{Ca}^{2+}$ concentration caused by the opening or closing of transducer channels is defined as:

$$
\left[\frac{\partial\left[\mathrm{Ca}^{2+}\right]}{\partial t}\right]_{\text {influx }}=\frac{-\bar{i}_{\mathrm{Ca}} \cdot p_{\mathrm{O}_{\mathrm{m}}}}{2 \cdot F \cdot \pi \cdot r_{\mathrm{a}}}
$$

where $I_{\mathrm{MT}}$ is the maximal $\mathrm{Ca}^{2+}$ current per stereocilium as defined in Equation A2, $F$ is Faraday's constant, $p_{\mathrm{o}_{\mathrm{m}}}$ is the open probability of the transducer estimated from experimental data, and $r_{\mathrm{a}}$ is the radius of the area over which $\mathrm{Ca}^{2+}$ ions enter (10 $\mathrm{nm}) . \mathrm{Ca}^{2+}$ is extruded by CaATPase pumps that are uniformly distributed in the hair bundle membrane and bind $\mathrm{Ca}^{2+}$ with a dissociation constant $K_{\mathrm{m}}=0.5 \mu \mathrm{M}$ (Garrahan and Rega, 1990). An inward $\mathrm{Ca}^{2+}$ leakage maintains the steady state at the stereociliary base (Sala and Hernández-Cruz, 1990). The combination of $\mathrm{Ca}^{2+}$ extrusion and leakage then can be defined as:

$$
\left[\frac{\partial\left[\mathrm{Ca}^{2+}\right]}{\partial t}\right]_{\mathrm{ext}}=\frac{\nu_{\max } \cdot A(r, z)}{V_{\mathrm{c}}} \cdot\left(\frac{\left[\mathrm{Ca}^{2+}\right]_{\mathrm{o}}}{\left[\mathrm{Ca}^{2+}\right]_{\mathrm{o}}+K_{\mathrm{m}}}-\frac{\left[\mathrm{Ca}^{2+}\right]}{\left[\mathrm{Ca}^{2+}\right]+K_{\mathrm{m}}}\right)
$$

where $\left[\mathrm{Ca}^{2+}\right]_{\mathrm{o}}=0.1 \mu \mathrm{M}$ is the initial steady-state concentration, $\nu_{\max }=3.32 \times 10^{-4} \mu$ moles $\cdot \mathrm{m}^{2} \cdot \mathrm{msec}^{-1}$ (based on 100 ions $\cdot \mathrm{sec}^{-1} \cdot \operatorname{pump}^{-1}$ and 2000 pumps $\left.\cdot \mu \mathrm{m}^{-2}\right)$ is the maximal velocity of transport, and $A(r, z)$ is the effective pumping area of a compartment $(r, z)$.

\section{Calcium buffers}

Fixed buffers will not contribute to the steady-state $\mathrm{Ca}^{2+}$ gradients (Naraghi and Neher, 1997), so only mobile buffers are considered. $\mathrm{Ca}^{2+}$ binding is assumed to have second order kinetics:

$$
\mathrm{Ca}^{2+}+B_{\mathrm{D}} \underset{k_{\mathrm{D}}^{-}}{\stackrel{k_{\mathrm{D}}^{+}}{\rightleftharpoons}} \mathrm{CaB}_{\mathrm{D}}
$$

where $B_{\mathrm{D}}$ and $\mathrm{Ca} B_{\mathrm{D}}$ are the $\mathrm{Ca}^{2+}$-free and $\mathrm{Ca}^{2+}$-bound diffusible buffers, and $k_{+}^{\mathrm{D}}$ and $k_{-}^{\mathrm{D}}$ are the binding and unbinding rate constants. The dissociation constant $k_{\mathrm{d}}^{\mathrm{D}}$ is equal to $k_{-}^{\mathrm{D}} / \mathrm{k}_{+}^{\mathrm{D}}$. Diff usion coefficients of $\mathrm{Ca}^{2+}$-free and $\mathrm{Ca}^{2+}$-bound diffusible buffers are assumed to be identical. If the $B_{\mathrm{D}}$ and $\mathrm{Ca} B_{\mathrm{D}}$ are treated as a single species, the net exchange of $\left[B_{\mathrm{D}}\right]$ and $\left[\mathrm{Ca} B_{\mathrm{D}}\right]$ between one compartment and its surrounding compartments becomes zero; i.e., the total buffer concentration remains fixed, and thus the spatial distribution of total buffer is unaffected by $\left[\mathrm{Ca}^{2+}\right]($ Neher, 1986; Roberts, 1994). Then, the rate of change of free $\left[\mathrm{Ca}^{2+}\right]$ produced by the diffusible buffer can be defined as:

$$
\left[\frac{\partial\left[\mathrm{Ca}^{2+}\right]}{\partial t}\right]_{\text {mobile }}=k_{\mathrm{D}}^{\mathrm{d}} \cdot k_{\mathrm{D}}^{+} \cdot\left(\left[B_{\mathrm{D}}^{\mathrm{T}}\right]-\left[B_{\mathrm{D}}\right]\right)-k_{\mathrm{D}}^{+} \cdot\left[\mathrm{Ca}^{2+}\right] \cdot\left[B_{\mathrm{D}}\right],
$$

with $\left[B_{\mathrm{T}}^{\mathrm{D}}\right]$ the total concentration of $B_{\mathrm{D}}$. The rate of changes of $\mathrm{Ca}^{2+}$-free and $\mathrm{Ca}^{2+}$-bound buffers can also be related to Equation A6:

$$
\left[\frac{\partial\left[B_{\mathrm{D}}\right]}{\partial t}\right]=-\left[\frac{\partial\left[\mathrm{Ca} B_{\mathrm{D}}\right]}{\partial t}\right]=\left[\frac{\partial\left[\mathrm{Ca}^{2+}\right]}{\partial t}\right]_{\text {mobile }}+D_{\mathrm{B}} \cdot \nabla^{2}\left[B_{\mathrm{D}}\right]=0
$$

where $\nabla^{2}\left[B_{\mathrm{D}}\right]$ is the differential operator defined in Equation A1. The relevant parameters are listed in Table 2.

\section{Integration}

A set of partial differential equations (PDEs) was integrated to calculate the spread of free $\mathrm{Ca}^{2+}$. The first PDE in Equation A7 determines the concentration of $\mathrm{Ca}^{2+}$-free diffusible buffer (BAPTA or calbindin) of each compartment and, using the same equation, the second PDE determines the concentration of $\mathrm{Ca}^{2+}$ free ATP. The third PDE integrates the various components giving the total rate of change of $\left[\mathrm{Ca}^{2+}\right]$, which is a summation of Equations A1, A3, A4, and A6:

$$
\begin{aligned}
\frac{\partial\left[\mathrm{Ca}^{2+}\right]}{\partial t}= & {\left[\frac{\partial\left[\mathrm{Ca}^{2+}\right]}{\partial t}\right]_{\text {dif usion }}+\left[\frac{\partial\left[\mathrm{Ca}^{2+}\right]}{\partial t}\right]_{\text {influx }} } \\
& +\left[\frac{\partial\left[\mathrm{Ca}^{2+}\right]}{\partial t}\right]_{\text {ext }}+\left[\frac{\partial\left[\mathrm{Ca}^{2+}\right]}{\partial t}\right]_{\text {mobile }} \\
& +\left[\frac{\partial\left[\mathrm{Ca}^{2+}\right]}{\partial t}\right]_{\mathrm{ATP}}=0 .
\end{aligned}
$$

Finite difference equations and boundary conditions are analogous to those described previously (Wu et al., 1996), with the exception that the $\left[\mathrm{Ca}^{2+}\right]$ at the bottom of the stereocilium was set to $0.1 \mu \mathrm{M}$ for all simulations. Initially, a random profile was assigned to the compartments, and the distributions were then optimized to satisfy Equations A6-A8. Successive overrelaxation with a checkerboard ordering method (Strikverda, 1989) was modified for variable grids (Wu et al., 1996) to compute iteratively the steady-state $\left[\mathrm{Ca}^{2+}\right]$ profiles. The compartment size in both the $r$ - and $z$-directions was increased incrementally with distance from the source, from $1 \mathrm{~nm}$ close to the channel up to 10 $\mathrm{nm}$ at $200 \mathrm{~nm}$ from the channel.

\section{REFERENCES}

Art JJ, Fettiplace R (1987) Variation of membrane properties in hair cells isolated form the turtle cochlea. J Physiol (Lond) 385:207-242.

Assad JA, Hacohen N, Corey DP (1989) Voltage dependence of adaptation and active bundle movements in bullfrog saccular hair cells. Proc Natl Acad Sci USA 86:2918-2922.

Baird RA, Steyger PS, Schuff NR (1997) Intracellular distribution and putative functions of calcium-binding proteins in the bullfrog vestibular otolith. Hear Res 103:85-100.

Benser ME, Marquis RE, Hudspeth AJ (1996) Rapid, active hair bundle movements in hair cells from the bullfrog's sacculus. J Neurosci 16:5629-5643.

Bredderman PJ, Wasserman RH (1974) Chemical composition, affinity for calcium, and some related properties of the vitamin D dependent calcium-binding protein. Biochemistry 13:1687-1694.

Chard PS, Bleakman D, Christakos S, Fullmer CS, Miller RJ (1993) Calcium buffering properties of calbindin D28k and parvalbumin in rat sensory neurons. J Physiol (Lond) 472:341-357.

Crawford AC, Fettiplace R (1980) The frequency selectivity of auditory nerve fibres and hair cells in the cochlea of the turtle. J Physiol (Lond) 306:79-125.

Crawford AC, Fettiplace R (1981a) Non-linearities in the responses of turtle hair cells. J Physiol (Lond) 315:317-338.

Crawford AC, Fettiplace R (1981b) An electrical tuning mechanism in turtle cochlear hair cells. J Physiol (Lond) 312:377-412.

Crawford AC, Fettiplace R (1985) The mechanical properties of ciliary bundles of turtle cochlear hair cells. J Physiol (Lond) 364:359-379.

Crawford AC, Evans MG, Fettiplace R (1989) Activation and adaptation of transducer currents in turtle hair cells. J Physiol (Lond) 419:405-434.

Crawford AC, Evans MG, Fettiplace R (1991) The actions of calcium on the mechano-electrical transducer current of turtle hair cells. J Physiol (Lond) 434:369-398. 
Crouch JJ, Schulte BA (1995) Expression of plasma membrane CaATPase in the adult and developing gerbil cochlea. Hear Res 92:112-119.

Denk W, Holt JR, Shepherd GMG, Corey DP (1995) Calcium imaging of single stereocilia in hair cells: localization of transduction channels at both ends of tip links. Neuron 15:1311-1321.

Eatock RA, Corey DP, Hudspeth AJ (1987) Adaptation of mechanoelectrical transduction in hair cells of the bullfrog's sacculus. J Neurosci 7:2821-2836.

Fettiplace R, Crawford AC (1978) The coding of sound pressure and frequency in cochlear hair cells of the terrapin. Proc R Soc Lond B Biol Sci 203:209-218.

Garrahan PJ, Rega AF (1990) Plasma membrane calcium pump. In: Intracellular calcium regulation (Bronner F, ed), pp 271-303. New York: Wiley Liss.

Hackney CM, Fettiplace R, Furness DN (1993) The functional morphology of stereociliary bundles on turtle cochlear hair cells. Hear Res 69:163-175.

Hall JD, Betarbet S, Jaramillo F (1997) Endogenous buffers limit spread of free calcium in hair cells. Biophys J 73:1243-1252.

Horn R, Marty A (1988) Muscarinic activation of ionic currents measured with a new whole-cell recording method. J Gen Physiol 92:145-159.

Hudspeth AJ (1982) Extracellular current flow and the site of transduction by vertebrate hair cells. J Neurosci 2:1-10.

Jaramillo F, Hudspeth AJ (1992) Localization of the hair cell's transduction channels at the hair bundle's top by iontophoretic application of a channel blocker. Neuron 7:409-420.

London RE, Rhee CK, Murphy E, Gabel S, Levy LA (1994) NMRsensitive fluorinated and fluorescent intracellular calcium ion indicators with high dissociation constant. Am J Physiol 266:C1313-C1322.

Lumpkin EA, Hudspeth AJ (1995) Detection of $\mathrm{Ca}^{2+}$ entry through mechanosensitive channels localizes the site of mechanoelectrical transduction in hair cells. Proc Natl Acad Sci USA 92:10297-10301.

Martin SR, Linse S, Johnson C, Bayley PM, Forsen S (1990) Protein surface charges and $\mathrm{Ca}^{2+}$ binding to individual sites in calbindin D9K: stopped flow studies. Biochemistry 29:4188-4193.

Naraghi M, Neher E (1997) Linearized buffered $\mathrm{Ca}^{2+}$ diffusion in microdomains and its implications for calculations of $\left[\mathrm{Ca}^{2+}\right]$ at the mouth of a calcium channel. J Neurosci 17:6961-6973.

Navaratnam DS, Escobar L, Covarrubias M, Oberholtzer JC (1995) Permeation properties and differential expression across the auditory receptor epithelium of an inward rectifier $\mathrm{K}^{+}$channel cloned from the chick inner ear. J Biol Chem 270:19238-19245.

Neher E (1986) Concentration profiles of intracellular calcium in the presence of a diffusible chelator In: Calcium electrogenesis and neuronal functioning (Heinemann U, Klee M, Neher E, Singer W, eds), pp $80-96$. Berlin: Springer.

Oberholtzer JC, Buettger C, Summers MC, Matschinsky FM (1988) The $28 \mathrm{kDa}$ calbindin-D is a major calcium-binding protein in the basilar papilla of the chick. Proc Natl Acad Sci USA 85:3387-3390.

Oliva C, Cohen IS, Mathias RT (1988) Calculations of time constants for intracellular diffusion in whole-cell patch configuration. Biophys $\mathrm{J}$ 54:791-799.

Pack AK, Slepecky NB (1995) Cytoskeletal and calcium-binding pro- teins in the mammalian organ of Corti; cell type-specific proteins displaying longitudinal and radial gradients. Hear Res 91:119-135.

Pethig R, Kuhn M, Payne R, Adler E, Chen T-H, Jaffe LF (1989) On the dissociation constants of BAPTA-type calcium buffers. Cell Calcium 10:491-498.

Rae J, Cooper K, Gates P, Watsky M (1991) Low access resistance perforated patch recordings with amphotericin B. J Neurosci Methods 37:15-26.

Ricci AJ, Fettiplace R (1997) The effects of calcium buffering and cyclic AMP on mechano-electrical transduction in turtle auditory hair cells. J Physiol (Lond) 501:111-124.

Ricci AJ, Fettiplace R (1998) Calcium permeation of the turtle hair cell's mechanotransducer channel and its relation to the composition of endolymph. J Physiol (Lond) 506:159-173.

Roberts WM (1993) Spatial calcium buffering in saccular hair cells. Nature 363:74-76.

Roberts WM (1994) Localization of calcium signals by a mobile calcium buffer in frog saccular hair cells. J Neurosci 14:3246-3262.

Sala F, Hernández-Cruz A (1990) Calcium diffusion modeling in a spherical neuron: relevance of buffering properties. Biophys $\mathrm{J}$ 57:313-324.

Shepherd GMG, Barres BA, Corey DP (1989) 'Bundle blot' purification and initial protein characterization of hair cell stereocilia. Proc Natl Acad Sci USA 86:4973-4977.

Stern MD (1992) Buffering of calcium in the vicinity of a channel pore. Cell Calcium 13:183-192.

Strickverda JC (1989) Finite difference schemes and partial differential equations. Pacific Grove: Wadsworth and Brooks.

Tsien RY (1980) New calcium indicators with high selectivity against magnesium and protons: design, synthesis, and properties of prototype structures. Biochemistry 19:2396-2404.

Tucker T, Fettiplace R (1995) Confocal imaging of calcium microdomains and calcium extrusion in turtle hair cells. Neuron 15:1323-1335.

Tucker T, Fettiplace R (1996) Monitoring calcium in turtle hair cells with a calcium-activated potassium channel. J Physiol (Lond) 494:613-626.

Yamoah EN, Gillespie PG (1996) Phosphate analogs block adaptation in hair cells by inhibiting adaptation-motor force production. Neuron 17:523-533.

Yamoah EN, Lumpkin EA, Dumont RA, Smith PJS, Hudpseth AJ, Gillespie PG (1998) Plasma membrane $\mathrm{Ca}^{2+}$-ATPase extrudes $\mathrm{Ca}^{2+}$ from hair cell stereocilia. J Neurosci 18:610-624.

Walker RG, Hudspeth, AJ (1996) Calmodulin controls adaptation of mechanoelectrical transduction by hair cells of the bullfrog's sacculus. Proc Natl Acad Sci USA 93:2203-2207.

Wu Y-C, Art JJ, Goodman MB, Fettiplace R (1995) A kinetic description of the calcium-activated potassium channel and its application to electrical tuning of hair cells. Prog Biophys Mol Biol 63:131-158.

Wu Y-C, Fettiplace R (1996) A developmental model for generating frequency maps in the reptilian and avian cochleas. Biophys $\mathrm{J}$ 70:2557-2570.

Wu Y-C, Tucker T, Fettiplace R (1996) A theoretical study of calcium microdomains in turtle hair cells. Biophys J 71:2256-2275.

Zhou Z, Neher E (1993) Mobile and immobile calcium buffers in bovine adrenal chromaffin cells. J Physiol (Lond) 469:245-273. 